\title{
Effects of genotype and dietary fish oil replacement with vegetable oil on the intestinal transcriptome and proteome of Atlantic salmon (Salmo salar)
}

Sofia Morais ${ }^{1 *}$, Tomé Silva², Odete Cordeiro², Pedro Rodrigues², Derrick R Guy ${ }^{3}$, James E Bron ${ }^{1}$, John B Taggart ${ }^{1}$, J Gordon Bell ${ }^{1}$ and Douglas R Tocher ${ }^{1}$

\begin{abstract}
Background: Expansion of aquaculture requires alternative feeds and breeding strategies to reduce dependency on fish oil (FO) and better utilization of dietary vegetable oil (VO). Despite the central role of intestine in maintaining body homeostasis and health, its molecular response to replacement of dietary FO by VO has been little investigated. This study employed transcriptomic and proteomic analyses to study effects of dietary VO in two family groups of Atlantic salmon selected for flesh lipid content, 'Lean' or 'Fat'.

Results: Metabolism, particularly of lipid and energy, was the functional category most affected by diet. Important effects were also measured in ribosomal proteins and signalling. The long-chain polyunsaturated fatty acid (LC-PUFA) biosynthesis pathway, assessed by fatty acid composition and gene expression, was influenced by genotype. Intestinal tissue contents of docosahexaenoic acid were equivalent in Lean salmon fed either a FO or VO diet and expression of LC-PUFA biosynthesis genes was up-regulated in VO-fed fish in Fat salmon. Dietary VO increased lipogenesis in Lean fish, assessed by expression of FAS, while no effect was observed on $\beta$-oxidation although transcripts of the mitochondrial respiratory chain were down-regulated, suggesting less active energetic metabolism in fish fed VO. In contrast, dietary VO up-regulated genes and proteins involved in detoxification, antioxidant defence and apoptosis, which could be associated with higher levels of polycyclic aromatic hydrocarbons in this diet. Regarding genotype, the following pathways were identified as being differentially affected: proteasomal proteolysis, response to oxidative and cellular stress (xenobiotic and oxidant metabolism and heat shock proteins), apoptosis and structural proteins particularly associated with tissue contractile properties. Genotype effects were accentuated by dietary VO.
\end{abstract}

Conclusions: Intestinal metabolism was affected by diet and genotype. Lean fish may have higher responsiveness to low dietary n-3 LC-PUFA, up-regulating the biosynthetic pathway when fed dietary VO. As global aquaculture searches for alternative oils for feeds, this study alerts to the potential of VO introducing contaminants and demonstrates the detoxifying role of intestine. Finally, data indicate genotype-specific responses in the intestinal transcriptome and proteome to dietary VO, including possibly structural properties of the intestinal layer and defence against cellular stress, with Lean fish being more susceptible to diet-induced oxidative stress.

\footnotetext{
* Correspondence: sofia.morais@irta.cat

'Institute of Aquaculture, University of Stirling, Stirling FK9 4LA, Scotland, UK

Full list of author information is available at the end of the article
} 


\section{Background}

Fish are important components of the human diet, being highly nutritious and valued as the main source of $n-3$ long-chain polyunsaturated fatty acids (LC-PUFA). These essential fatty acids, mainly eicosapentaenoic acid (EPA) and docosahexaenoic acid (DHA), have wellknown health-promoting properties, including protection against a range of cardiovascular and inflammatory diseases, and neurological disorders [1]. With population growth and increasing awareness of the importance of fish consumption as part of a healthy diet, worldwide demand for seafood continues to grow. However, as traditional fisheries are largely in decline, aquaculture must meet this demand. Aquaculture is the fastest-growing food production sector with an average annual growth rate of $6.6 \%$, accounting for $46 \%$ of total fish supply [2]. In the European and American continents, aquaculture production is largely dominated by salmonid species, mainly Atlantic salmon, and feeds for such carnivorous species have traditionally relied on fishmeal (FM) and fish oil (FO) from wild stocks. Recent estimates indicated that $88.5 \%$ of global production of FO was used by the aquaculture sector, with salmonid culture taking the largest share (56\%) [3]. With ever increasing demands for aquafeeds and reduction in fisheries landings, the availability of FO and FM seriously limits the growth of aquaculture production and there is an urgent need to find more sustainable alternatives.

Vegetable oils (VO) can replace FO in salmon feeds without compromising fish growth or condition although, at high levels of replacement, tissue levels of n-3 LC-PUFA are significantly reduced [4,5]. The effects of FO replacement by $\mathrm{VO}$ are becoming well characterized in the hepatic transcriptome of salmonids [6-10], and other species [11]. However, studies on intestinal transcriptome are few and restricted to effects of replacement of FM by plant proteins, particularly soybean meal $[12,13]$, given its potential to cause enteritis. It is now clear that intestine in salmonids is not simply a site for reacylation and packaging of dietary lipids but it also has important roles in fatty acid metabolism, including LCPUFA biosynthesis $[14,15]$. Furthermore, dietary VO can induce major histological changes in fish enterocytes, originating mostly from supranuclear lipid droplet formation, possibly due to altered reacylation mechanisms and decreased phospholipid synthesis [16-18]. In some cases, these accumulations were large enough to be deemed pathological $[19,20]$. A recent study investigating effects of dietary FO replacement by $\mathrm{VO}$ on intestinal transcriptome in Atlantic cod indicated potential effects on lipid absorption and transport and suggested morphological and structural changes to the intestinal muscle layer [21]. Furthermore, both this and a previous study on Atlantic salmon showed significant effects on expression of genes involved in cell proliferation and apoptosis [22]. Therefore, there is indication that intestine may be affected by changes in lipid components of feed formulations. Given its crucial roles in nutrient absorption, protection against the entry of pathogens, and immune function [23], further attention is warranted and impacts of FO replacement require investigation in intestine, particularly in salmon where important changes in diet formulation are already being applied. This study is a large-scale analysis of the effects of replacement of dietary FO by $\mathrm{VO}$ on the transcriptome and proteome of Atlantic salmon intestine. Furthermore, given recent interest in evaluating genetic selection as a feasible strategy, in conjunction with changes in commercial feed formulation, to meet worldwide demand for farmed fish without compromising animal welfare or nutritional value $[9,10,24]$, two groups of Atlantic salmon families, Lean and Fat, were studied to examine the potential effects of genetic background. This experiment was performed in parallel with another microarray study looking at effects in the hepatic transcriptome, analysing samples from the same individuals $[9,10]$, enabling a global and comprehensive assessment of the physiological and molecular effects of FO replacement by $\mathrm{VO}$ in Atlantic salmon, including potential interactions with genotype.

\section{Results}

\section{Microarray analysis}

Two way-ANOVA of the cDNA array dataset returned 1409, 1626 and 862 significant genes for the factors diet, genotype and diet $\times$ genotype interaction, respectively. Detailed analysis was restricted to the top 100 most significant features, which were categorised according to biological function, based on mammalian homolog genes. Metabolism, particularly of lipid and energy, was the functional category most affected by diet accounting for $39-41 \%$ of the top 100 annotated genes (Table 1), and showing highest diet $\times$ genotype interaction (Additional file 1). Diet also impacted translation (17\%; mostly ribosomal proteins) and signalling (17\%). In contrast, genotype affected less markedly metabolism (21\%), whereas structural proteins (25\%; mostly different types of collagen) and proteins involved in the regulation of transcription (21\%) predominated (Table 2).

Gene Ontology (GO) enrichment analysis was performed on the complete significant lists, enabling identification of GO terms significantly enriched in the input entity list, in comparison to the whole array, providing clues as to which biological processes might be particularly altered in the experimental conditions being compared. It revealed no significant enrichment of GO terms in the genotype list, while 20 and 7 GO terms were significantly enriched in the diet and interaction 
Table 1 Intestine transcripts corresponding to the top 100 most significant features exhibiting differential expression between diets

\begin{tabular}{llll}
\hline Accession no & Gene & Vo/FO & $p-$ value \\
\cline { 2 - 3 } & & Lean & Fat \\
\hline
\end{tabular}

Metabolism (39\%)

Lipid metabolism (9\%)

DW590668

CK888998

CK884623

CK885725

AF478472

Fatty aldehyde dehydrogenase

Ethanolamine kinase 1

Epidermis-type arachidonate lipoxygenase 3

Protein containing a beta-ketoacyl synthase domain

Delta- 5 fatty acyl desaturase

Energy metabolism/generation of precursor metabolites (11\%)

\section{CK885194}

Cytochrome c oxidase subunit $5 \mathrm{~A}$

bra_snb_03E12

NADH dehydrogenase subunit 1

EG649067

Ubiquinol-cytochrome $\mathrm{c}$ reductase core protein 1

CK884638

Uncoupling protein

CK890974

Mitochondrial calcium-dependent solute carrier SCaMC-2

EG648806

NADH dehydrogenase (ubiquinone) 1 beta subcomplex 9

Protein and amino acid metabolism (9\%)

$\begin{array}{ll}\text { CK877521 } & \text { Kunitz-type protease inhibitor } 2 \text { precursor } \\ \text { DW590246 } & \text { Betaine aldehyde dehydrogenase } \\ \text { CK885180 } & \text { Fumarylacetoacetate hydrolase domain-containing protein 2B } \\ \text { CK897653 } & \text { Ubiquitin-conjugating enzyme E2 A } \\ \text { CK885145 } & \text { Lysosomal protective protein precursor (Cathepsin A) }\end{array}$

Carbohydrate metabolism (5\%)

$\begin{array}{ll}\text { EG649263 } & \text { Endosulfine alpha } \\ \text { CK885545 } & \text { Glucose transporter type 8 }\end{array}$

Xenobiotic and oxidant metabolism (5\%)

$\begin{array}{ll}\text { CK885392 } & \text { Catalase } \\ \text { CO472279 } & \text { Cytochrome P450 } 1^{\text {a }} \\ \text { CK898307 } & \text { Selenoprotein H-like protein }\end{array}$

Transport/ intracellular trafficking (5\%)

EG647578

Calcium-activated potassium channel subunit alpha 1

EG648841

Sodium-coupled neutral amino acid transporter 2

EG648303

Mitochondrial import receptor subunit TOM20 homolog

Regulation of transcription (13\%)

$\begin{array}{ll}\text { CK898304 } & \text { C-Maf } \\ \text { CK890154 } & \text { Butyrate response factor 2 } \\ \text { EG647831 } & \text { Proliferation-associated 2G4 b } \\ \text { AM041851 } & \text { Enhancer trap locus homolog 1 } \\ \text { CK885179 } & \text { Steroid receptor RNA activator 1 } \\ \text { CK884728 } & \text { Butyrate response factor 1 } \\ \text { CK879187 } & \text { Enhancer of polycomb homolog 1 }\end{array}$

Translation (17\%)

CK878380

40 ribosomal protein $\mathrm{S} 18$

DW591873

$\begin{array}{rrr}-1.1 & -1.2 & 0.0003 \\ 1.2 & 1.2 & 0.0008 \\ 1.4 & 1.1 & 0.0010 \\ 1.4 & 1.6 & 0.0017 \\ 1.2 & 2.5 & 0.0019\end{array}$

$-1.2$

$-1.1$

0.0000

$-1.3$

$-1.2$

0.0000

$-1.2$

$-1.1$

0.0004

$-1.3$

$-1.3$

0.0019

$-1.5$

0.0021

$-1.1$

1.0

0.0022

1.2

0.0002

$-1.4$

0.0005

$-1.4$

0.0007

1.2

1.1

0.0012

0.0014

0.0005

1.0

$-1.0$

0.0013

0.0000

0.0004

0.0013

$\begin{array}{rrr}1.3 & 1.2 & 0.0005 \\ -1.2 & -1.2 & 0.0007 \\ -1.1 & -1.1 & 0.0011\end{array}$

$-1.1$

0.0011

0.0000

0.0001

$-1.3$

0.0003

- 1.1

0.0004

$-1.3$

0.0007

1.1

0.0011

1.4

$$
1.4
$$

0.0020 
Table 1 Intestine transcripts corresponding to the top 100 most significant features exhibiting differential expression between diets (Continued)

\begin{tabular}{|c|c|c|c|c|}
\hline EG648644 & 605 ribosomal protein L29 & -1.1 & -1.2 & 0.0011 \\
\hline DW590580 & $40 \mathrm{~S}$ ribosomal protein $\mathrm{S} 5$ & -1.2 & -1.2 & 0.0011 \\
\hline CK880046 & 40 S ribosomal protein $\$ 28$ & -1.1 & -1.2 & 0.0017 \\
\hline EG649167 & $60 S$ ribosomal protein L37a & -1.1 & -1.2 & 0.0017 \\
\hline EG648512 & 605 ribosomal protein $L 41$ & -1.1 & -1.2 & 0.0017 \\
\hline CK886042 & 605 ribosomal protein L31 & -1.1 & -1.3 & 0.0021 \\
\hline CK895350 & 605 ribosomal protein L36 & -1.1 & -1.1 & 0.0021 \\
\hline
\end{tabular}

Signalling/Signal transduction (17\%)

\begin{tabular}{|c|c|c|c|c|}
\hline CK874863 & Proto-oncogene serine/threonine-protein kinase & 1.1 & 1.1 & 0.0002 \\
\hline CK881266 & Mitogen-activated protein kinase kinase kinase kinase 1 & 1.2 & 1.2 & 0.0002 \\
\hline CK878590 & Serine/threonine protein kinase (Tribbles homolog 2) & -1.1 & -1.3 & 0.0004 \\
\hline AJ425351 & Tensin-like C1 domain-containing & -2.0 & -1.2 & 0.0006 \\
\hline CK885079 & Sonic hedgehog-like protein & 1.3 & 1.0 & 0.0008 \\
\hline CN181161 & TGF-beta type II receptor & 1.1 & 1.1 & 0.0009 \\
\hline EG649257 & Serine/threonine-protein kinase VRK3 & -1.1 & -1.2 & 0.0009 \\
\hline CK886267 & Guanylate cyclase $2 \mathrm{C}$ & 1.1 & 1.1 & 0.0011 \\
\hline CK884467 & Serine/threonine-protein phosphatase $2 \mathrm{~A}$ regulatory subunit $\mathrm{B}$ & -1.4 & -1.3 & 0.0020 \\
\hline \multicolumn{5}{|c|}{ Structural proteins (7\%) } \\
\hline mus_snm_13F09 & Myosin heavy chain & -1.2 & -1.1 & 0.0002 \\
\hline CK885118 & Cardiac tropomyosin & 1.0 & 1.1 & 0.0013 \\
\hline CK883354 & Troponin C & 1.2 & 1.2 & 0.0017 \\
\hline EG647866 & Tubulin alpha chain & -1.2 & -1.2 & 0.0020 \\
\hline \multicolumn{5}{|c|}{ Immune response (2\%) } \\
\hline BM414177 & Liver-expressed antimicrobial peptide 2 & 1.5 & 1.4 & 0.0022 \\
\hline \multicolumn{5}{|l|}{ Miscellaneous } \\
\hline CK884634 & Ezrin-radixin-moesin binding phosphoprotein 50 & 1.1 & 1.1 & 0.0003 \\
\hline EG648821 & Transposase & -1.1 & -1.2 & 0.0004 \\
\hline CK883634 & Poly [ADP-ribose] polymerase 12 & 1.3 & 1.1 & 0.0006 \\
\hline CK885090 & Claudin 15 & 1.2 & 1.1 & 0.0008 \\
\hline DW589291 & Transposase & -1.3 & -1.3 & 0.0009 \\
\hline CK878888 & Splicing factor, arginine/serine-rich 3 & -1.3 & -1.2 & 0.0013 \\
\hline CK885098 & RNA-binding protein with multiple splicing 2 & -1.4 & -1.2 & 0.0013 \\
\hline CK891747 & Occludin & -1.2 & -1.2 & 0.0014 \\
\hline CK888908 & All-trans-retinol 13,14-reductase precursor & 1.1 & 1.2 & 0.0017 \\
\hline CK880622 & Cyclin G1 & -1.1 & -1.2 & 0.0019 \\
\hline CK885604 & Methylenetetrahydrofolate dehydrogenase (NADP+ dependent) 1-like & -1.6 & -1.3 & 0.0020 \\
\hline CK891699 & Barrier-to-autointegration factor & -1.1 & -1.2 & 0.0020 \\
\hline CK879123 & Hemoglobin subunit beta & 1.5 & 1.0 & 0.0022 \\
\hline
\end{tabular}

Annotated features (67\% of all clones) are arranged by categories of biological function (with percentages of distribution of genes within each category being indicated) and, within these, by decreasing significance (assessed by two-way ANOVA). Also indicated are the GenBank accession numbers for each clone (or, when not available, the probe number) and the expression ratio between fish fed VO and those fed FO, for each genotype (Lean and Fat).

lists, respectively. GO terms enriched in the diet list included structural constituents of ribosome, structural molecule activity, cytosolic ribosome, cytosol, ribosomal subunit, translation, cellular biosynthetic process, gene expression, macromolecule and biopolymer biosynthetic process and other related terms. This was explained by the large number of ribosomal proteins, components of both the $40 \mathrm{~S}$ and $60 \mathrm{~S}$ subunits, which were down- 
Table 2 Intestine transcripts corresponding to the top 100 most significant features exhibiting differential expression between family groups

\begin{tabular}{llll}
\hline Accession no & Gene & Lean/Fat & $p$ value \\
\cline { 2 - 3 } & & FO & Vo \\
\hline
\end{tabular}

Metabolism (21\%)

Lipid metabolism (5\%)

CK874747

Acylglycerol kinase

B|468033

Energy metabolism/generation of precursor metabolites (2\%)

CK890974

Mitochondrial calcium-dependent solute carrier SCaMC-2

Protein and amino acid metabolism (12\%)

EG647485

DW591059

AJ425553

DW592187

26 proteasome complex subunit DSS1

CK878109

Xenobiotic and oxidant metabolism (2\%)

C0472279
ATP-binding cassette sub-family A member 1

Proteasome subunit beta type-8 precursor

Heat shock protein Hsp-16

265 proteasome non-ATPase regulatory subunit 9

Heat shock protein 60 kDa

Cytochrome P450 1A

$-1.0$

$-1.1$

$-1.1$

$-1.3$

1.2

$-1.2$

1.5

1.2

$-1.2$

$-1.4$

1.1

Post-GPI attachment to proteins factor 2
$-1.1$

$-1.6$

$-1.6$

Transport/ intracellular trafficking (5\%)

CK886307

DW588251

Regulation of transcription (21\%)

CK885079

$\begin{array}{ll}\text { CK877881 } & \text { Forkhead box Q1 } \\ \text { CK884548 } & \text { Proline-rich nuclear receptor coactivator 2 } \\ \text { CK885013 } & \text { Forkhead box protein F1 } \\ \text { CK891975 } & \text { Y-box binding protein-2 } \\ \text { DW589341 } & \text { Signal transducer/activator of transcription Stat1 } \\ \text { CN181282 } & \text { Bromodomain containing protein 3 } \\ \text { CK884407 } & \text { C-Myc-binding protein } \\ \text { CK895950 } & \text { Transcription factor CP2-like } \\ \text { EG648473 } & \text { BTB/POZ domain-containing protein } \\ \text { Translation (7\%) } & \\ \text { CN181322 } & \text { 40S ribosomal protein S4 } \\ \text { CK885979 } & \text { Ribonuclease UK114 } \\ \text { EG648042 } & \text { Eukaryotic translation initiation factor 3, subunit J }\end{array}$

Signalling/Signal transduction (16\%)

CO471793

Rho GDP-dissociation inhibitor 1

CK885560

Protein tyrosine phosphatase non-receptor type 9

Sonic hedgehog-like protein

EG648038

Kalirin, RhoGEF kinase

DW589610

Chimaerin 1

CK897590

Growth factor receptor-bound protein 2

EG647545

Protein tyrosine phosphatase receptor type D

$-1.4$

$-1.1$

1.1

$-1.1$

$-1.2$

$-1.1$

$-1.3$

$-1.5$

$-1.1$
0.0000

0.0003

0.0004

0.0000

0.0001

0.0002

0.0008

0.0009

0.0003

0.0006

0.0007

0.0000

0.0001

0.0003

0.0003

0.0004

0.0007

0.0007

0.0007

0.0009

0.0002

0.0005

0.0009

0.0000

0.0004

0.0004

0.0005

0.0005

0.0009

$1.2 \quad 0.0009$

$\begin{array}{ll}1.7 & 0.0000\end{array}$ 
Table 2 Intestine transcripts corresponding to the top 100 most significant features exhibiting differential expression between family groups (Continued)

\begin{tabular}{|c|c|c|c|c|}
\hline EG648135 & Osteonectin & 1.3 & 1.5 & 0.0000 \\
\hline CK899058 & Collagen alpha 3 type VI & 1.5 & 1.5 & 0.0002 \\
\hline CK879405 & Collagen alpha 2 type $\mathrm{VI}$ & 1.3 & 1.5 & 0.0002 \\
\hline EG649361 & Collagen alpha 2 type I & 1.5 & 1.7 & 0.0005 \\
\hline EG649013 & Collagen alpha 3 type I & 1.4 & 1.5 & 0.0005 \\
\hline mus_mfo_15A10 & Troponin-l isoform 3 & 1.4 & 1.6 & 0.0007 \\
\hline CK876833 & Keratocan & -1.0 & 1.6 & 0.0007 \\
\hline DW590534 & Collagen alpha 2 type I & 1.5 & 1.6 & 0.0010 \\
\hline CK892271 & Collagen alpha 2 type $V$ & 1.2 & 1.4 & 0.00010 \\
\hline CK873441 & Collagen alpha1 type $\mathrm{VI}$ & 1.2 & 1.4 & 0.0010 \\
\hline \multicolumn{5}{|c|}{ Immune response (5\%) } \\
\hline AJ425527 & T-cell immunoglobulin and mucin domain-containing protein 4 & 1.1 & 1.1 & 0.0001 \\
\hline EG649194 & Mannose-binding protein C & 1.4 & 1.4 & 0.0003 \\
\hline \multicolumn{5}{|l|}{ Miscellaneous } \\
\hline AM041770 & Preimplantation protein 3 & -1.3 & -1.2 & 0.0000 \\
\hline EG649106 & Ornithine decarboxylase antizyme 2 & 1.4 & 1.1 & 0.0002 \\
\hline CK884355 & Guanylin precursor & 1.2 & 1.4 & 0.0002 \\
\hline CK879185 & Aminolevulinate, delta-, synthetase 1 & -2.0 & -1.1 & 0.0002 \\
\hline CK885814 & Similar to p53-associated parkin-like cytoplasmic protein & 1.2 & 1.1 & 0.0002 \\
\hline CK886214 & Septin-7 & 1.1 & 1.1 & 0.0003 \\
\hline BM414079 & Tumor protein D52-like 2 & -1.1 & -1.3 & 0.0003 \\
\hline BM413818 & Splicing factor, proline- and glutamine-rich & 1.2 & 1.2 & 0.0003 \\
\hline CK874550 & Follistatin-related protein 1 & 1.1 & 1.3 & 0.0004 \\
\hline DW589104 & Nucleoside diphosphate kinase 6 & 1.1 & 1.1 & 0.0005 \\
\hline DW592207 & Deoxyhypusine synthase & 1.5 & 1.6 & 0.0007 \\
\hline CK892359 & HCLS1-associated protein X-1 & -1.2 & -1.1 & 0.0007 \\
\hline B|468158 & Nuclear protein 1 & -1.0 & -1.6 & 0.0009 \\
\hline AJ425003 & Lamina-associated polypeptide 2 & 1.2 & 1.1 & 0.0010 \\
\hline CK899283 & Small EDRK-rich factor 2 & 1.3 & 1.5 & 0.0010 \\
\hline CK885090 & Claudin 15 & -1.2 & -1.1 & 0.0011 \\
\hline
\end{tabular}

Annotated features (60\% of all clones) are arranged by categories of biological function (with percentages of distribution of genes within each category being indicated) and, within these, by decreasing significance (assessed by two-way ANOVA). Also indicated are the GenBank accession numbers for each clone (or, when not available, the probe number) and the expression ratio between Lean and Fat fish fed either FO or VO.

regulated by dietary VO (Table 1$)$. In contrast, several $\Delta 6$-desaturase $(\Delta 6 \mathrm{fad})$ clones showing a diet $\times$ genotype interaction (see Additional file 1) caused a significant enrichment of the GO terms oxidoreductase activity, stearoyl-CoA 9-desaturase activity, unsaturated fatty acid biosynthetic activity/metabolic processes and very long chain fatty acid (VLCFA) biosynthetic activity/metabolic processes.

\section{RT-qPCR analysis of gene expression}

The expression of several genes significantly affected or related to processes affected by the two factors in the microarray analysis was determined by RT-qPCR (Table 3). For diet, a reasonably good match was found for $\Delta 5$ fatty acyl desaturase ( $\Delta 5 \mathrm{fad}$ ), NADH dehydrogenase subunit 1 (NADH1), proliferation-associated 2G4b (PA2G4), 60S acidic ribosomal protein (RP60S), proliferating cell nuclear antigen (PCNA; also known as cyclin) and cytochrome P450 1A (CYP1A), particularly in the Fat group where fold-changes were generally more pronounced and significant. No change in expression of uncoupling protein 2 (UCP2) with diet was measured while, for myosin heavy chain (MYO) and methylenetetrahydrofolate dehydrogenase (NADP+ dependent) 1like (MTHFD1), RT-qPCR indicated a change opposite to that suggested by microarray. Regarding genotype, a good match was obtained for CYP1A, proteasome subunit beta type- 8 precursor (PSMB8) and alpha 2 type I 
Table 3 Relative expression of genes assayed by RT-qPCR

\begin{tabular}{|c|c|c|c|c|c|c|c|c|}
\hline \multirow[t]{3}{*}{ Genes } & \multicolumn{4}{|c|}{ VO/FO } & \multicolumn{4}{|c|}{ Lean/Fat } \\
\hline & \multicolumn{2}{|c|}{ Lean } & \multicolumn{2}{|c|}{ Fat } & \multicolumn{2}{|c|}{ FO } & \multicolumn{2}{|c|}{ vo } \\
\hline & Ratio & $p$ value & Ratio & $p$ value & Ratio & $p$ value & Ratio & $p$ value \\
\hline \multicolumn{9}{|c|}{ Microarray validation } \\
\hline$\Delta 5 f a d(D)$ & 1.72 & ns & 4.34 & 0.005 & 2.49 & ns & -1.01 & ns \\
\hline $\mathrm{NADH} 1$ (D) & -1.03 & ns & -1.28 & 0.05 & 1.00 & ns & 1.24 & ns \\
\hline UCP2 (D) & -1.10 & ns & 1.08 & ns & -1.10 & ns & -1.28 & 0.003 \\
\hline MTHFD1 (D) & 1.20 & ns & -1.09 & ns & -1.08 & ns & 1.22 & ns \\
\hline PA2G4 (D) & -1.27 & ns & -1.23 & 0.032 & 1.11 & ns & 1.1 & ns \\
\hline RP60S (D) & -1.02 & ns & -1.69 & 0.023 & 1.13 & ns & 1.9 & 0.006 \\
\hline MYO (D) & 1.77 & 0.034 & 1.22 & ns & -1.35 & ns & 1.08 & ns \\
\hline PCNA (D) & -1.14 & ns & -1.27 & ns & 1.08 & ns & 1.20 & ns \\
\hline CYP1A (D+G) & 1.71 & 0.004 & 1.81 & 0.023 & -2.22 & 0.003 & -2.38 & 0.001 \\
\hline $\mathrm{ABCA} 1(\mathrm{G})$ & 1.24 & ns & 1.17 & ns & 1.21 & ns & 1.28 & 0.015 \\
\hline $\operatorname{PSMB8}(\mathrm{G})$ & -100.00 & ns & 1.87 & 0.033 & -16.67 & 0.026 & $<-1000$ & 0.000 \\
\hline TAGLN (G) & 1.23 & ns & -1.02 & ns & -1.03 & ns & 1.22 & ns \\
\hline $\operatorname{COL1A2~(G)~}$ & 1.31 & ns & -1.06 & ns & 1.47 & ns & 2.06 & 0.001 \\
\hline \multicolumn{9}{|c|}{ LC-PUFA biosynthesis and regulation } \\
\hline$\Delta 6$ fad_a & 1.11 & ns & 2.96 & 0.008 & 1.76 & ns & -1.52 & ns \\
\hline elovl5a & 1.08 & ns & 1.2 & ns & 1.03 & ns & -1.08 & ns \\
\hline elovl5b & -1.19 & ns & 1.92 & 0.031 & 1.54 & ns & -1.47 & ns \\
\hline elovl2 & 1.2 & ns & 14.74 & 0.003 & 4.89 & ns & -2.50 & ns \\
\hline \multicolumn{9}{|c|}{ Fatty acid synthesis } \\
\hline FAS & 1.49 & 0.010 & 1.20 & ns & 1.05 & ns & 1.31 & ns \\
\hline \multicolumn{9}{|c|}{ Fatty acid oxidation } \\
\hline ACO & 1.18 & ns & 1.28 & ns & 1.19 & ns & 1.09 & ns \\
\hline CPT1 & 1.23 & ns & -1.09 & ns & -1.16 & ns & 1.15 & ns \\
\hline \multicolumn{9}{|c|}{ Regulation of lipid metabolism } \\
\hline PPARa & 1.14 & ns & 1.38 & ns & 1.26 & ns & 1.04 & ns \\
\hline PPARB & 1.03 & ns & 1.03 & ns & -1.02 & ns & -1.02 & ns \\
\hline PPARY & 1.52 & ns & 1.60 & 0.036 & 1.21 & ns & 1.15 & ns \\
\hline \multicolumn{9}{|c|}{ Xenobiotic and oxidative stress } \\
\hline GST & -1.30 & ns & 1.07 & ns & 1.21 & ns & -1.14 & ns \\
\hline MT-A & -1.82 & $0.051^{*}$ & -1.05 & ns & -1.25 & ns & -2.13 & 0.007 \\
\hline CAT & 1.57 & 0.036 & 1.26 & ns & -1.52 & ns & -1.22 & ns \\
\hline SOD & -1.20 & ns & -1.04 & ns & 1.21 & ns & 1.04 & ns \\
\hline \multicolumn{9}{|l|}{ Apoptosis } \\
\hline CASP3B & 1.22 & 0.045 & 1.22 & ns & -1.04 & ns & -1.04 & ns \\
\hline CASP6A/B & 1.30 & ns & 1.37 & ns & -1.14 & ns & -1.20 & ns \\
\hline
\end{tabular}

fad: Fatty acyl desaturase ( $\Delta 5$ and $\triangle 6$ activities); NADH1: NADH dehydrogenase subunit 1; UCP2: Uncoupling protein 2; elovl: MTHFD1: Methylenetetrahydrofolate dehydrogenase (NADP+ dependent) 1-like; PA2G4: Proliferation-associated 2G4b; RP60S: 60S acidic ribosomal protein; MYO: Myosin heavy chain; PCNA: Proliferating cell nuclear antigen; CYP1A: Cytochrome P4501A; ABCA1: ATP-binding cassette sub-family A member 1; PSMB8: Proteasome subunit beta type-8 precursor; TAGLN: Transgelin 2; COL1A2: Collagen type I alpha 2; elovl2: Elongase 2; FAS: Fatty acid synthase; ACO: Acyl-CoA oxidase; CPT1: Carnitine palmitoyltransferase I; PPARs; Peroxisome proliferator-activated receptors; GST: glutathione S-transferase; MT-A: Metallothionein A; CAT: catalase; SOD: superoxide dismutase; CASP; caspase.

*Only marginally non-significant.

Genes correspond to features significantly affected by either diet (D) or genotype (G) in the microarray analysis or involved in biological processes being analysed in further detail. Values are normalized (by cofilin-2 and elf-1 a) gene expression ratios between fish fed VO in relation to FO for each family group or of Lean fish in relation to the Fat group when fed either one of the diets. Values in bold are significantly different, at p<0.05 (REST 2008 ); ns - non-significant. 
collagen (COL1A2), while transgelin 2 (TAGLN) expression did not differ between family groups, and for ATPbinding cassette sub-family A member 1 (ABCA1) there was an inverse change in expression.

As well as validation above, RT-qPCR was used to further analyse genes/pathways identified by microarray and published data as potentially interesting, including lipid metabolism, xenobiotic and oxidative stress, and apoptosis. One was LC-PUFA biosynthesis, given that $\Delta 5 \mathrm{fad}$ was significantly affected by diet in the microarray analysis, with a stronger response in Fat fish, whereas $\Delta 6$ fad showed a significant diet $\times$ genotype interaction (supplementary file 1) confirmed by RT-qPCR. The $\Delta 6$ fad transcript was only significantly up-regulated in Fat fish fed VO, compared to FO, and Lean fish showed higher levels of $\Delta 6$ fad expression than Fat fish when fed FO, while the opposite trend was noted when fish were fed VO. Fatty acyl elongases (elovl's) were also quantified and their expression (except elovl5a) broadly followed that of fads: significantly upregulated when dietary VO replaced FO in the Fat group. Additionally, elovl $5 \mathrm{~b}$ and, particularly, elovl2 showed a trend for increased expression (high fold-change) in Lean fish, compared to Fat fish, when fed FO, while an opposite trend was observed when salmon were fed VO. Although genes involved in fatty acid synthesis and oxidation showed few significant differences, expression of fatty acid synthase (FAS) was up-regulated in fish fed VO, but only in Lean fish. The expression of peroxisome proliferator-activated receptors (PPARs), involved in the regulation of multiple lipid metabolism genes, was determined but only PPAR $\gamma$ showed any significant change, being up-regulated in the Fat group when dietary VO replaced FO. Of the xenobiotic and oxidative metabolism genes assayed, apart from CYP1A, only catalase (CAT) was affected by diet (up-regulated in fish fed VO) and only significantly in the Lean family. In contrast, metallothionein A (MT-A) showed higher expression in Fat fish, but only when fed VO, while a marginal down-regulation was observed when comparing $\mathrm{VO}$ and FO-fed fish in the Lean group. Of genes related to apoptosis, CASP3B was up-regulated by VO in Lean fish whereas a similar fold-change was marginally non-significant in the Fat fish.

\section{Intestine fatty acid composition}

The levels of most fatty acids in pyloric caeca were affected by diet, whereas genotype had no significant

Table 4 Fatty acid compositions (\% of total fatty acids) and lipid contents (\% of wet weight) of intestinal tissue of Lean and Fat family groups fed diets containing either FO or VO

\begin{tabular}{|c|c|c|c|c|c|c|c|}
\hline & \multicolumn{2}{|c|}{ FO } & \multicolumn{2}{|c|}{ vo } & \multicolumn{3}{|c|}{ Two-way ANOVA } \\
\hline & Fat & Lean & Fat & Lean & D & G & $D \times G$ \\
\hline \multicolumn{8}{|l|}{ Fatty acid } \\
\hline Total saturated & $23.70 \pm 1.21$ & $22.82 \pm 1.09$ & $18.57 \pm 0.73$ & $20.08 \pm 1.38$ & 0.000 & 0.742 & 0.066 \\
\hline Total monoenes & $38.25 \pm 7.15$ & $44.45 \pm 5.31$ & $44.98 \pm 2.38$ & $39.34 \pm 4.49$ & 0.717 & 0.928 & 0.046 \\
\hline $18: 2 n-6$ & $4.19 \pm 0.67$ & $4.51 \pm 0.24$ & $13.14 \pm 0.59$ & $11.28 \pm 1.12$ & 0.000 & 0.139 & 0.041 \\
\hline $18: 3 n-6$ & $0.10 \pm 0.02$ & $0.10 \pm 0.02$ & $0.28 \pm 0.12$ & $0.25 \pm 0.13$ & 0.003 & 0.611 & 0.611 \\
\hline $20: 2 n-6$ & $0.57 \pm 0.06$ & $0.58 \pm 0.07$ & $1.54 \pm 0.40$ & $1.65 \pm 0.06$ & 0.000 & 0.199 & 0.510 \\
\hline $20: 3 n-6$ & $0.17 \pm 0.06$ & $0.14 \pm 0.02$ & $1.01 \pm 0.12$ & $1.47 \pm 0.26$ & 0.000 & 0.056 & 0.019 \\
\hline $20: 4 n-6$ & $1.20 \pm 0.60$ & $0.85 \pm 0.31$ & $0.74 \pm 0.18$ & $1.40 \pm 0.29$ & 0.785 & 0.419 & 0.016 \\
\hline $22: 4 n-6$ & $0.08 \pm 0.06$ & $0.05 \pm 0.06$ & $0.00 \pm 0.00$ & $0.09 \pm 0.07$ & 0.337 & 0.337 & 0.038 \\
\hline $22: 5 n-6$ & $0.21 \pm 0.06$ & $0.16 \pm 0.07$ & $0.07 \pm 0.02$ & $0.12 \pm 0.05$ & 0.002 & 1.000 & 0.128 \\
\hline Total n-6 PUFA & $6.51 \pm 0.18$ & $6.38 \pm 0.36$ & $16.79 \pm 0.86$ & $16.27 \pm 0.67$ & 0.000 & 0.410 & 0.781 \\
\hline $18: 3 n-3$ & $1.46 \pm 0.38$ & $1.67 \pm 0.21$ & $4.79 \pm 0.53$ & $3.71 \pm 0.75$ & 0.000 & 0.211 & 0.021 \\
\hline $18: 4 n-3$ & $1.36 \pm 0.60$ & $1.67 \pm 0.66$ & $0.85 \pm 0.31$ & $0.55 \pm 0.20$ & 0.002 & 0.712 & 0.127 \\
\hline $20: 3 n-3$ & $0.27 \pm 0.05$ & $0.33 \pm 0.14$ & $0.67 \pm 0.18$ & $0.62 \pm 0.04$ & 0.000 & 0.768 & 0.384 \\
\hline $20: 4 n-3$ & $1.77 \pm 0.28$ & $2.16 \pm 0.46$ & $0.97 \pm 0.13$ & $0.83 \pm 0.10$ & 0.000 & 0.504 & 0.061 \\
\hline $20: 5 n-3$ & $6.55 \pm 0.55$ & $5.79 \pm 0.62$ & $3.60 \pm 0.90$ & $4.40 \pm 0.72$ & 0.000 & 0.682 & 0.058 \\
\hline $22: 5 n-3$ & $2.82 \pm 0.81$ & $2.30 \pm 0.74$ & $1.57 \pm 0.36$ & $2.54 \pm 0.77$ & 0.157 & 0.530 & 0.052 \\
\hline $22: 6 n-3$ & $16.68 \pm 6.68$ & $11.65 \pm 5.65$ & $6.97 \pm 1.58$ & $11.50 \pm 3.10$ & 0.057 & 0.943 & 0.050 \\
\hline Total n-3 PUFA & $30.90 \pm 5.94$ & $25.56 \pm 5.19$ & $19.41 \pm 2.18$ & $24.15 \pm 3.76$ & 0.015 & 0.962 & 0.042 \\
\hline Total PUFA & $38.06 \pm 5.96$ & $32.73 \pm 5.42$ & $36.45 \pm 2.08$ & $40.59 \pm 3.16$ & 0.206 & 0.794 & 0.059 \\
\hline Total lipids & $7.50 \pm 3.75$ & $9.56 \pm 3.81$ & $6.97 \pm 1.07$ & $4.59 \pm 1.05$ & 0.081 & 0.804 & 0.111 \\
\hline
\end{tabular}

Results are means \pm SD $(n=4)$ and p-values of two-way ANOVA are presented for diet $(D)$, genotype $(G)$ and interaction between both factors. 
effect (Table 4). However, some fatty acids also showed a significant diet $\times$ genotype interaction, indicating that the effect of diet depended on the genetic background of the fish. For instance, interactions were observed for some LC-PUFA as a result of higher levels being found in the Lean group, compared to Fat, when fish were fed VO, while the reverse was observed when fed FO. Another unexpected result was that similar levels of DHA in FO- and VO-fed Lean fish meant that, in spite of substantial differences in Fat fish fed the two diets, the effect of diet on DHA was marginally nonsignificant. Similarly, levels of EPA and 22:5n-3 between FO- and VO-fed fish were noticeably closer in the Lean group.

\section{Proteomic analysis}

Of the protein spots identified as being differentially expressed between diets or genotypes (Additional files 2 and 3), only 17 and 29 could be excised and, of these, only 9 and 20, respectively, returned reliable identifications by peptide fragment fingerprinting (Figure 1). Proteins significantly up-regulated by dietary $\mathrm{VO}$ are likely implicated in xenobiotic/drug metabolism (epoxide hydrolase 2, EPHX2), protection from oxidative stress (hemopexin-like protein, HPX and peroxiredoxin-1, PRDX1) and induction of apoptosis and inflammatory responses (galectin-2, LGALS2). Those proteins downregulated by dietary $\mathrm{VO}$ included proteins responsible for protein folding and involved in signalling (2-peptidylprolyl

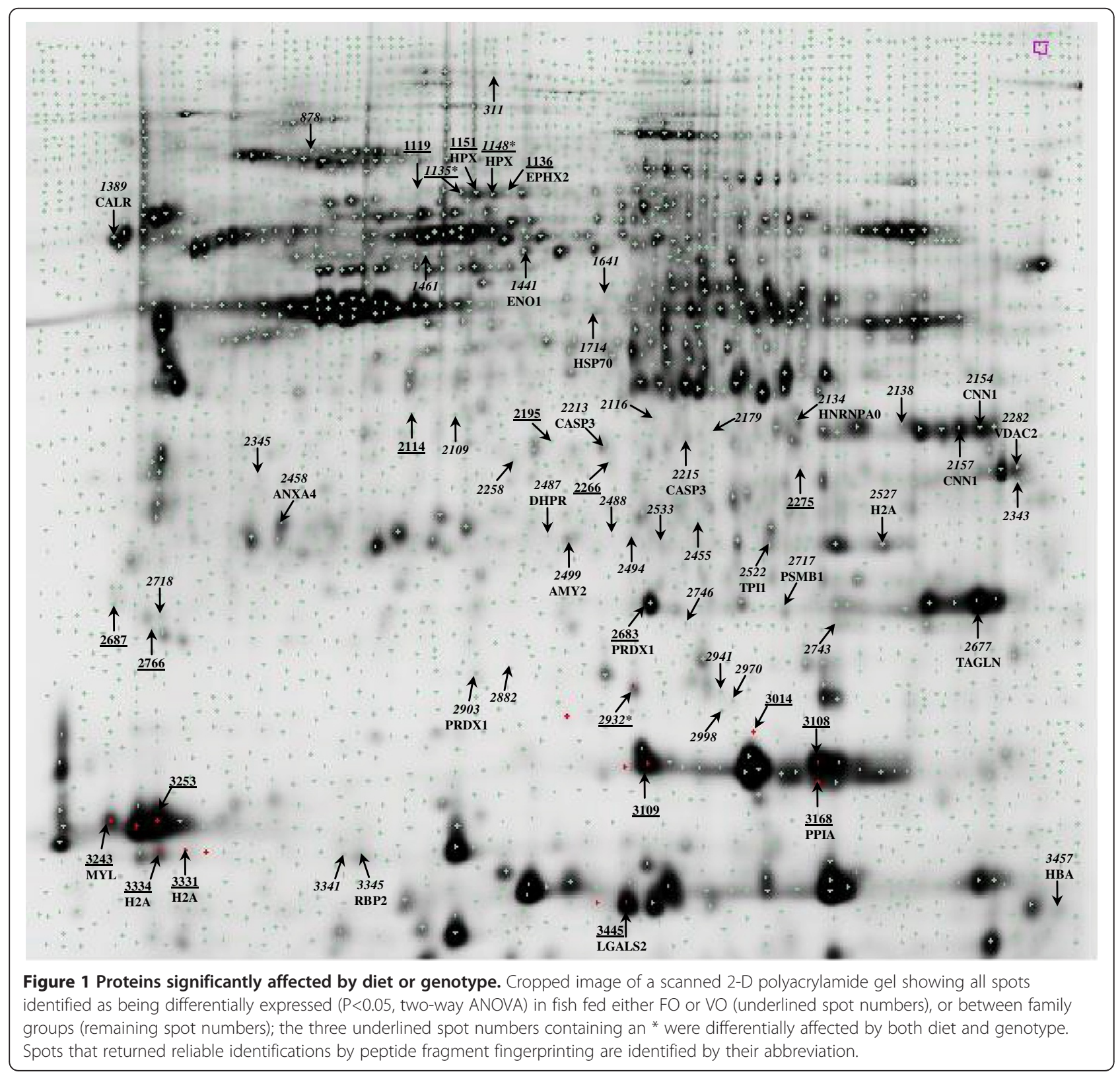


Table 5 Proteins differentially regulated by diet

\begin{tabular}{|c|c|c|c|c|c|c|c|c|c|}
\hline Spot No & Protein ID & $\begin{array}{l}\text { Accession No. } \\
\text { (NCBInr) }\end{array}$ & $\begin{array}{l}\text { Theoretical Mw } \\
\text { (KDa)/pl }\end{array}$ & $\begin{array}{l}\text { Protein } \\
\text { Score }^{a}\end{array}$ & $\begin{array}{l}\text { No. Matched peptides } \\
\text { (MS/MS) }^{\text {b }}\end{array}$ & Best score peptide & VO/FO Lean & VO/FO Fat & p-value \\
\hline 1136 & Epoxide hydrolase 2 (EPHX2) & gb|ACI33129.1| & $54.2 / 5.52$ & 84 & 1 & GGLFVGLPDEIPR & 1.23 & 1.40 & 0.0190 \\
\hline 1148 & Hemopexin-like protein* (HPX) & emb|CAA92147.1| & $50.4 / 5.61$ & 169 & 1 & VHLDAITSDDAGNIYAFR & 1.32 & 1.56 & 0.0002 \\
\hline 1151 & Hemopexin-like protein* (HPX) & ref|NP_001104617.1| & $51.0 / 6.18$ & 161 & 1 & VHLDAITSDDAGNIYAFR & 1.38 & 1.54 & 0.0001 \\
\hline 2683 & Peroxiredoxin 1 (PRDX1) & gb|ACl67145.1| & $22.0 / 6.42$ & 757 & 8 & SISTDYGVLKEDEGIAYR & 1.14 & 1.09 & 0.0310 \\
\hline 3168 & $\begin{array}{l}\text { 2-peptidylprolyl isomerase A } \\
\text { (PPIA) }\end{array}$ & ref|NP_001135161.1| & $17.5 / 7.61$ & 101 & 1 & VYFDITIGDTPAGR & -1.46 & -1.18 & 0.0170 \\
\hline 3243 & $\begin{array}{l}\text { Myosin light chain smooth } \\
\text { muscle isoform (MYL) }\end{array}$ & ref|NP_998803.1| & $16.9 / 4.47$ & 100 & 2 & EAFLLFDR & -1.23 & -1.11 & 0.0490 \\
\hline 3331 & $\begin{array}{l}\text { similar to } \mathrm{H} 2 \mathrm{~A} \text { histone family, } \\
\text { member } \mathrm{H}(\mathrm{H} 2 \mathrm{~A})\end{array}$ & ref|XP_001521566.1| & $13.3 / 10.84$ & 74 & 1 & AGLQFPVGR & -1.58 & -1.18 & 0.0250 \\
\hline 3334 & Histone $\mathrm{H}_{2} \mathrm{~A}^{* *}(\mathrm{H} 2 \mathrm{~A})$ & emb|CAA25528.1| & $13.7 / 10.88$ & 37 & 1 & AGLQFPVGR & -1.48 & -1.18 & 0.0210 \\
\hline 3445 & Galectin 2 (LGALS2) & gb|ACN10131.1| & $14.8 / 5.93$ & 314 & 2 & SGASSFSINIGHDSDNYALHFNPR & 1.17 & 1.15 & 0.0170 \\
\hline
\end{tabular}

${ }^{a}$ The protein score probability limit (where $\mathrm{P}<0.05$ ) is 73 .

b Peptides with confidence interval above $95 \%$ were considered.

* Equivalent to warm-temperature-acclimation-related-65 kDa-protein.

**Same protein identification obtained by MS/PMF (peptide mass fingerprinting): Score $=76 ; 7$ peptides matched.

Only reliable identifications of Actinopterygii, obtained by mass spectrometry (MALDI-TOF-MS/MS) analysis and searches in MASCOT, NCBI and ExPASy (Mw/pl) databases are shown. Expression ratios between fish fed

VO and FO diets are given for each family group, as well as p-value for diet (two-way ANOVA, DeCyder V7.0). 
Table 6 Proteins differentially regulated by genotype

\begin{tabular}{|c|c|c|c|c|c|c|c|c|c|}
\hline Spot No & Protein ID & $\begin{array}{l}\text { Accession No. } \\
\text { (NCBInr) }\end{array}$ & $\begin{array}{l}\text { Theoretical Mw } \\
(\mathrm{KDa}) / \mathrm{pl}\end{array}$ & $\begin{array}{l}\text { Protein } \\
\text { Score }^{a}\end{array}$ & $\begin{array}{l}\text { No. Matched peptides } \\
\text { (MS/MS) }^{\mathbf{b}}\end{array}$ & Best score peptide & Lean/Fat FO & Lean/Fat VO & $p$-value \\
\hline 1148 & Hemopexin-like protein* (HPX) & emb|CAA92147.1| & $50.4 / 5.61$ & 169 & 1 & VHLDAITSDDAGNIYAFR & -1.09 & -1.29 & 0.0270 \\
\hline 1389 & Calreticulin precursor (CALR) & gb|ACI32936.1| & 47.6/4.33 & 81 & 2 & FEPFSNEGK & -1.28 & -1.33 & 0.0026 \\
\hline 1441 & Alpha-enolase (ENO1) & ref|NP_001133366.1| & $47.0 / 5.91$ & 405 & 3 & AAVPSGASTGIYEALELR & 1.28 & 1.2 & 0.0066 \\
\hline 1714 & Heat shock protein 70 (HSP70) & ref|NP_990334.1| & $70.8 / 5.47$ & 111 & 1 & IINEPTAAAIAYGLDKK & 1.16 & 1.77 & 0.0260 \\
\hline 2134 & $\begin{array}{l}\text { Heterogeneous nuclear } \\
\text { ribonucleoprotein AO (HNRNPAO) }\end{array}$ & gb|ACl67551.1| & 28.8/9.10 & 235 & 2 & LFVGGLNVDTDDDGLRK & -1.19 & -1.09 & 0.0460 \\
\hline 2154 & Calponin 1 (CNN1) & ref|NP_001139857.1| & $33.2 / 8.56$ & 565 & 4 & KINTSPQNWHQLENIGNFVR & -1.34 & -1.51 & 0.0350 \\
\hline 2157 & Calponin $1^{* * *}(\mathrm{CNN1})$ & ref|NP_001139857.1| & $33.2 / 8.56$ & 43 & 1 & YDPQKEEELR & -1.34 & -1.47 & 0.0240 \\
\hline 2213 & Caspase 3 (CASP3) & ref|NP_001133393.1| & $31.0 / 5.97$ & 254 & 2 & IPVEADFLYAYSTAPGYYSWR & -1.15 & -1.24 & 0.0300 \\
\hline 2215 & Caspase 3 (CASP3) & ref|NP_001133393.1| & $31.0 / 5.97$ & 279 & 2 & VANDQTVQQIQQLLSK & -1.14 & -1.31 & 0.0130 \\
\hline 2282 & $\begin{array}{l}\text { Voltage-dependent anion } \\
\text { channel 2-2 (VDAC2) }\end{array}$ & gb|ACH71030.1| & $30.1 / 8.85$ & 214 & 1 & VNNNSLVGVGYTQTLRPGVK & -1.24 & -1.19 & 0.0160 \\
\hline 2458 & Annexin A4 (ANXA4) & gb|ACl69495.1| & $28.4 / 5.22$ & 218 & 3 & NHLLQVFK & -1.14 & -1.11 & 0.0300 \\
\hline 2487 & $\begin{array}{l}\text { Dihydropteridine reductase } \\
\text { (DHPR) }\end{array}$ & gb|ACl67281.1| & $15.7 / 8.46$ & 81 & 1 & QSWTSTISSHLATR & -1.14 & -1.11 & 0.0300 \\
\hline 2499 & $\begin{array}{l}\text { Pancreatic alpha-amylase } \\
\text { precursor (AMY2) }\end{array}$ & ref|NP_001036176.1| & $57.4 / 6.89$ & 86 & 1 & ALVFVDNHDNQR & -1.37 & -1.27 & 0.0021 \\
\hline 2522 & $\begin{array}{l}\text { Triosephosphate isomerase } \\
\text { 1b (TPI1) }\end{array}$ & ref|NP_001133174.1| & $26.6 / 7.63$ & 336 & 2 & LDPNTEWCGAPSIYLEFAR & 1.26 & 1.16 & 0.0009 \\
\hline 2527 & Histone cluster 1 (H2A) & ref|NP_001086775.1| & $14.0 / 10.88$ & 94 & 1 & AGLQFPVGR & 1.12 & 1.11 & 0.0074 \\
\hline 2677 & Transgelin (TAGLN) & gb|ACM09025.1| & 21.7/7.69 & 219 & 1 & DGCVLSELINSLHK & -1.61 & -1.35 & 0.0350 \\
\hline 2717 & $\begin{array}{l}\text { Proteasome beta } 1 \text { subunit } \\
\text { (PSMB1) }\end{array}$ & ref|NP_001003889.1| & $26.1 / 6.32$ & 87 & 1 & GAVYSFDPVGSYQR & -1.29 & -1.12 & 0.0140 \\
\hline 2903 & Peroxiredoxin-1(PRDX1) & gb|ACl67145.1| & $22.0 / 6.42$ & 115 & 1 & QITINDLPVGR & -1.62 & -1.99 & 0.0069 \\
\hline 3345 & $\begin{array}{l}\text { Retinol-binding protein II, } \\
\text { cellular (RBP2) }\end{array}$ & ref|NP_001139954.1| & $15.6 / 5.44$ & 70 & 2 & AIDIDFATR & -1.32 & -1.1 & 0.0330 \\
\hline 3457 & Alpha globin (HBA) & emb|CAA65949.1| & $15.1 / 9.19$ & 170 & 2 & TYFSHWADLSPGSAPVK & 1.03 & 2.09 & 0.0320 \\
\hline
\end{tabular}

${ }^{\text {aT }}$ The protein score probability limit (where $\mathrm{P}<0.05$ ) is 73 .

${ }^{\mathrm{b}}$ Peptides with confidence interval above $95 \%$ were considered.

* Equivalent to warm-temperature-acclimation-related-65 kDa-protein.
*** Same protein identification obtained by MS/PMF (peptide mass fingerprinting): Score $=193 ; 27$ peptides matched.

*** Same protein identification obtained by MS/PMF (peptide mass fingerprinting): Score $=193 ; 27$ peptides matched.
Only reliable identifications of Actinopterygii, obtained by mass spectrometry (MALDI-TOF-MS/MS) analysis and searches in MASCOT, NCBI and ExPASy (Mw/pl) databases are shown. Expression ratios between Lean and Fat family groups are given for each dietary treatment, as well as p-value for genotype (two-way ANOVA, DeCyder V7.0). 
isomerase A, PPIA), actin-based motility (myosin light chain, MYL) and DNA replication, repair or transcription (histone H2A, H2A) (Table 5). Proteins affected by genotype encompass a variety of pathways, of which only a few are related to metabolism, namely carbohydrate (alphaenolase, ENO1; pancreatic alpha-amylase precursor, AMY2; triosephosphate isomerase 1b, TPI1), folate (dihydropteridine reductase, DHPR) or retinol (retinol-binding protein II, RBP2) metabolism (Table 6). Other proteins may have potentially multiple roles but can broadly be assigned roles in response to oxidative and cellular stress (HPX; PRDX; heat shock protein 70, HSP70), oxygen transport (alpha globin, HBA), signal transduction (calreticulin, CALR), transcription/RNA repair (heterogeneous nuclear ribonucleoprotein A0, HNRNPA0; histone H2A, $\mathrm{H} 2 \mathrm{~A}$ ), apoptosis (CASP3), cellular transport, potentially also associated with apoptosis (voltage-dependent anion channel 2-2, VDAC2; annexin A4, ANX4), and proteolysis (proteasome beta 1 subunit, PSMB1). As with the microarray analysis, a few proteins with a more structural function and particularly associated with tissue contractile properties were affected by genotype, showing lower levels in Lean fish. These included calponin-1 (CNN1) and transgelin (TAGLN), the latter which was also found to be significantly affected by microarray, albeit up-regulated in Lean fish. Most proteins significantly affected by genotype showed lower levels of expression in the Lean group, with the exception of ENO1, HSP70, TPI1, H2A and HBA.

\section{Discussion}

Dietary plant ingredients can induce chronic intestinal inflammatory conditions in salmonids that can ultimately result in carcinogenesis [25]. This extreme reaction is rare and usually associated with soy protein at high levels [26]. Dietary n-3 LC-PUFA have important antiinflammatory and anti-carcinogenic effects in mammalian intestine [23]. Therefore, use of feeds containing high percentages of plant proteins combined with replacement of $\mathrm{FO}$ by $\mathrm{VO}$, as is now prevalent in the industry, requires studies on dietary effects on intestinal transcriptomes and proteomes. However, interpretation of the data was difficult as the effects on dietary treatments and/or family groups were subtle, as also observed in liver transcriptome [9], and is typical of this type of experiment $[6,8,11,27]$. Partly as a consequence, validation of the microarray data gave variable results, from perfect match, to opposite changes in a few, although effects observed in the microarray, with fold changes as low as 1.2 (e.g., NADH1 and PA2G4) were validated by RT-qPCR. In view of the whole genome duplication event that occurred in salmonids [28], gene expression studies are often more challenging due to the presence of highly similar genes which may hybridize with cDNA probes presenting low specificity, further complicated if similar transcripts, corresponding to duplicated genes, are differentially regulated [10]. Nonetheless, the presence of several features related to specific processes in both the transcriptomic and proteomic analysis gave supporting evidence to the pathways likely differentially affected by dietary oil and genetic background related to flesh adiposity.

\section{Intestinal LC-PUFA biosynthesis capacity is differentially affected by diet and genotype}

Considering whether genetic selection for fish families showing better adaptation to more sustainable feeds might be a viable approach to develop aquaculture, one outcome of this investigation was to establish if effects of diet on expression of LC-PUFA biosynthesis genes depended on genotype, as shown in the liver transcriptome of these fish [9]. This was not seen in the hepatic transcriptome of European sea bass families showing different growth rates when fed a vegetable diet but, in this, case similar LC-PUFA profiles were also noted in both genotypes in response to the vegetable diet [11]. In both salmon tissues, differences in n-3 LC-PUFA content between fish fed $\mathrm{FO}$ or $\mathrm{VO}$ were smaller in the Lean family group. This was due to higher levels of n-3 LC-PUFA in Lean salmon, compared to Fat, when fish were fed VO, but higher amounts in the Fat family group when fed FO. However in liver, up-regulation of LC-PUFA biosynthesis when fish were fed $\mathrm{VO}$ was much larger in the Lean family group, whereas in intestine the same individuals only showed significant up-regulation in Fat fish. This appears contradictory but can be explained by the differential tissue n-3 LC-PUFA contents. Although the difference was smaller in Lean fish compared to Fat fish in both tissues, in liver there was still a considerable difference in n-3 LC-PUFA levels between fish fed FO or $\mathrm{VO}$, while in intestine levels were similar. PUFA have important activities on transcription factors, either as direct ligands or through effects on membrane composition [29], affecting transcription of many genes involved in lipid metabolism, including desaturases and elongases [30,31]. In salmon, regulation of genes of LC-PUFA biosynthesis that are known to respond to dietary composition, i.e., $\Delta 5 \mathrm{fad}, \Delta 6 \mathrm{fad}$, elovl5b and elovl2 [32-34], appear to show high plasticity and are likely under feedback regulation by tissue n-3 LC-PUFA. Both studies suggest that the Lean family group may show an enhanced response to low dietary n-3 LC-PUFA, with greater up-regulation of biosynthesis when fed VO. In contrast to liver, this response was sufficient in intestine to maintain tissue n-3 LC-PUFA, particularly DHA, at similar levels to fish fed FO. Considering that differences in desaturase expression between the Fat and Lean fish were only significant when FO but not VO, was fed, suggests that the likely mechanism is through negative 
feedback by high levels of n-3 LC-PUFA rather than positive feedback from low levels of LC-PUFA and/or higher levels of shorter chain precursors.

\section{Other dietary effects on lipid metabolism}

Transcriptional regulation of desaturases and elongases by LC-PUFA may involve both PPAR $\alpha$ and sterol regulatory element binding protein 1c (SREBP-1c) [30,31]. In liver, expression of $\Delta 5 \mathrm{fad}, \Delta 6 \mathrm{fad}$, elovl2, PPAR $\alpha$, and possibly PPAR $\beta$, appeared co-ordinately regulated by diet depending on genotype, while PPAR $\gamma$ was not affected [9]. In intestine, however, expression of PPAR $\alpha$ and PPAR $\beta$ was not affected by either diet or genotype, while PPAR $\gamma$ was up-regulated by dietary VO, significantly in Fat fish. This suggests that dietary regulation of lipid metabolism genes in fish intestine might differ to mammals, where PPAR $\alpha$ showed differential expression in response to dietary EPA and DHA in murine intestine [35]. Reasons for differential regulation of PPARs between salmon liver and intestine are unclear, but may be due to different patterns of tissue expression. In plaice and seabream, there was no nutritional regulation (fasting/feeding) of PPARs in the intestine, where PPAR $\gamma$ was the dominant isotype, in contrast to liver where PPAR $\alpha$ was dominant [36]. PPAR $\gamma$ in both mammals and fish is predominantly expressed in adipose tissue and promotes adipocyte differentiation and lipid storage [36-38]. In mammals, PPAR $\gamma$ activates the expression of genes characteristic of mature adipocytes and adipogenesis, including FAS $[37,38]$ and hence the expression of PPAR $\gamma$, up-regulated in salmon fed VO, might be related to increased expression of FAS. However, increased PPAR $\gamma$ expression was only significant in Fat fish whereas FAS was significantly up-regulated only in Lean salmon. As fish PPAR $\gamma$ is functionally the most different of the three isotypes compared to mammalian PPARs, and is expressed more widely in fish tissues that in mammals, other mechanisms and functions may underlie the observed regulation [35].

In this study, the hypotriglyceridemic effect of LCPUFA, well established in mammals [39,40], was also observed in salmon intestine. Lipogenesis was downregulated in FO-fed fish, as demonstrated by decreased FAS expression (RT-qPCR) and the presence of a transcript containing a beta-ketoacyl synthase domain, a component of FAS (microarray). The differences in FAS expression were not as marked as in liver [9] and were only significant in Lean fish but, together with the LCPUFA biosynthesis data, demonstrate the active role of salmon intestine in lipid metabolism [21]. However, despite up-regulation of lipogenesis by dietary VO, lipid accumulation in enterocytes was lower than in fish fed FO, contrary to previous reports of $\mathrm{VO}$ promoting lipid accumulation in enterocytes [16-18].
In contrast, the hypotriglyceridemic effect of LC-PUFA did not involve the typical increase in $\beta$-oxidation [39], reported in mice intestine [36,40]. As in liver, no changes were observed in the expression of $\beta$-oxidation genes carnitine palmitoyltransferase I (CPT1) and acyl-CoA oxidase (ACO) [10]. Nonetheless, effects of dietary lipid on energy metabolism were observed in intestine. In particular, UCP and transcripts involved in the mitochondrial electron transport chain, including components of cytochrome c oxidase, NADH1 and ubiquinol-cytochrome c reductase complexes, and the mitochondrial metabolite transporter SCaMC-2, were slightly down-regulated by dietary VO, possibly suggesting reduced energetic metabolism. EPA may act as a mitochondrial proliferator in both rat and salmon liver [41,42], which might also explain this result.

\section{Vegetable oils as potential sources of contaminants in alternative diets for aquaculture?}

The use of FO in feeds has also been questioned in relation to levels of persistent organic pollutants, POPs [43], whereas $\mathrm{VO}$ are generally considered safer alternatives to dietary FO [44]. However, results suggested that VO had greater impact on xenobiotic metabolism in salmon intestine than FO, with the transcriptome and proteome both showing up-regulation of transcripts and proteins involved in detoxification and protection from oxidative stress in fish fed VO. This was surprising, considering expression of these genes has been associated with FO supplementation and higher levels of organic contaminants and/or increased peroxidative susceptibility of LC-PUFA $[22,45,46]$. In particular, and linked to a detoxification role, up-regulation of CYP1A transcript and epoxide hydrolase 2 (EPHX2) protein was found in fish fed VO. Cytochrome P450 1A metabolizes many exogenous and endogenous molecules, including pollutants (e.g., polychlorinated biphenyls-PCBs, polycyclic aromatic hydrocarbons-PAHs, dioxins and dibenzofurans) as well as several metabolic products (e.g., steroids, bile acids). Its expression is sensitive to low levels of contaminants and therefore it is a commonly used marker [47,48]. Lipid peroxidation and antioxidant enzymes are also biomarkers for environmental xenobiotic contamination in fish, as the catalytic actions of detoxifying enzymes like CYP1A produce high levels of reactive oxygen species (ROS) $[49,50]$. We observed up-regulation of CAT and of a selenoprotein transcript, as well as of HPX and PRDX1 proteins in salmon fed VO. CAT and PRDX1 catalyze the decomposition of hydrogen peroxide [51], hemopexin prevents heme-mediated oxidative stress [52], and selenoproteins have diverse roles, including selenium transport and antioxidant defense [53]. Expression of other genes involved in protection from oxidative stress like GST and SOD were not affected, but MT-A was down- 
regulated in the Lean family group fed VO. MT-A, besides having an antioxidant role, also protects against heavy metal toxicity and maintains physiological zinc homeostasis [54] and hence could be responding to contaminants more abundant in FO (e.g., heavy metals) [55].

Previous analysis of contaminants in comparable feeds using the same standard FO and a similar VO blend, showed that levels of several POPs, including organochlorine pesticides, and heavy metals were substantially lower, but polycyclic aromatic hydrocarbons $(\mathrm{PAH})$ were 10-fold increased in the $\mathrm{VO}$ diet compared to the FO diet [55]. PAH derive from incomplete combustion of organic compounds and can be found in high concentrations in fats, including $\mathrm{VO}$, through multiple routes of contamination, before, during or after oil processing [56]. They are metabolized by both CYP1A1 and EPHX2, among other enzymes, and CYP1A1 is induced by PAH in mammals [57]. Therefore, higher PAH levels in the VO diet might explain, at least partly, the results obtained in the present study although, unlike POPs, $\mathrm{PAHs}$ are not persistent and are readily eliminated from fish tissues [58].

High doses of PAH result in significant intestinal hyperplasia in fish, with an increase in cell proliferation and faster epithelial turnover [59]. Previous studies on intestinal gene expression in fish indicated a reduction in cell proliferation or differentiation associated with dietary FO replacement by VO $[21,22]$, possibly due to lower levels of membrane LC-PUFA and reduced oxidative stress [22]. In the present study, no major impact on cell proliferation was apparent in the intestinal transcriptome or proteome data. Two transcripts related to cell proliferation, PA2G4 and cyclin G1, were slightly downregulated in fish fed $\mathrm{VO}$, but in mammals these have opposing effects $[60,61]$ and, furthermore, two mammalian PA2G4 isoforms have been shown to have opposite effects in cellular proliferation [62] and hence results are inconclusive.

Previously, expression of caspases, effectors of controlled cell death or apoptosis, was affected by replacement of dietary FO by VO in fish [21,22]. Apoptosis is particularly important in organs with high rates of cellular turnover such as intestine but, in addition to maintaining normal gut function, apoptosis may be affected by pathological or toxic conditions, including those induced by environmental chemical contaminants [63,64]. In the present study, expression of CASP3B was up-regulated in salmon fed $\mathrm{VO}$, particularly in the Lean family group and a similar, non-significant trend was observed for CASP6A/B. As ROS are important signalling molecules in apoptotic processes, these results could be linked to a cytotoxic effect causing increased oxidative stress in $\mathrm{VO}$ [64]. Relevant to the above was the up-regulation of galectin 2 (LGALS2) in the proteome of salmon fed VO.
Galectins are pleiotropic regulators of immune functions and are up-regulated by injury and infectious conditions, have well-recognized modulatory roles in mammalian intestinal inflammatory diseases, and their mode of action involves induction of apoptosis $[65,66]$. The lack of major effects on cell proliferation and only slight upregulation of CASP3 and LGALS2 suggests that any contaminant doses experienced by the fish were unlikely to have caused any serious morphophysiological damage in the intestine. As similar trends were not seen in the hepatic transcriptome of these individuals [9], this may suggest intestine can potentially metabolize and detoxify xenobiotics present in the diet. Furthermore, there were no growth or general performance issues with these fish [5]. Therefore, the data do not imply abnormal gastrointestinal functions or effects on final product quality.

\section{Effect of genotype in intestinal transcriptome and proteome}

Contrary to diet, genotype did not have a major impact on metabolism genes, apart from transcripts related to the proteasomal degradation pathway including a strong down-regulation of PSMB8 in Lean fish, particularly fed VO. This gene has been recently found to have a molecular evolution history that suggests a very strong selective pressure for its functional dimorphism to be maintained in vertebrates [67]. Two different alleles, Atype and F-type, can be found in basal vertebrate species, including Atlantic salmon. The PSMB8F lineage was lost in common ancestors of higher teleosts and tetrapods but was then independently revived de novo through the appearance of F-type alleles within the PSMB8A lineage. In this study we did not find evidence of significant differences between families groups for the A-type allele in the transcriptomic analysis as the probe showing significant variation between families in the microarray corresponded to the PSMB8F allele. Hence, it was also the F-type transcript that was validated by RT-qPCR, using type-F specific primers. However, further studies would be required to confirm this and to assess the functional significance of this result. On the other hand, expression of PSMB1 was down-regulated in the intestine proteome of Lean fish. Proteolysis through this pathway is essential for many cellular processes, including the cell cycle, signalling, cellular defence and responses to oxidative stress [68]. Therefore, this response might be related to defence against cellular stress, as another difference between the two family groups was related to xenobiotic and oxidant metabolism. Apart from lower expression of a CYP1A transcript in Lean fish, two proteins with antioxidant roles, HPX and PRDX, were down-regulated in the proteome of Lean compared to Fat fish. Alpha globin, or haemoglobin alpha (HBA), a major component of blood and potent mediator of oxidative stress, can have 
both protective and damaging effects depending on complex interactions in $\mathrm{H}_{2} \mathrm{O}_{2}$-rich environments [69]. However, given its opposite regulation to HPX, whose main role is to scavenge heme and protect from its toxic effects [52], up-regulation of HBA in Lean fish may indicate heme-mediated oxidative stress.

The apoptotic pathway may be differentially affected by genotype, with down-regulation of CASP3, VDAC2 and ANXA4 in the Lean family group, the latter two transport proteins having well-recognized roles in apoptosis $[70,71]$. In contrast, heat shock proteins that protect against environmental stresses were increased in the intestine transcriptome and proteome of Lean salmon. This response could be associated with the observed changes in the ubiquitin-proteasome degradation system, as the systems have been functionally coupled in mammals. Thus, moderate exposure to a heat shock can cause a transient increase in intracellular proteolysis by the ubiquitin-proteasome pathway, followed by a phase of slower or even inhibited protein degradation [72,73]. Furthermore, Pirkkala et al. [74] demonstrated transcriptional induction of heat shock genes when proteasome activity was down-regulated. However, judging by the fold-changes, these effects are only relevant when fish were fed VO, and hence could be more related to dietary changes. Collectively, the data may indicate higher sensitivity of Lean fish to environmental or endogenous stresses due to replacement of dietary FO by VO.

The predominant influence of genotype was in the expression of intestinal transcripts of structural proteins, particularly collagen alpha chains, but also osteonectin, TAGLN, troponin I and keratocan, which were upregulated in Lean fish, whereas troponin $\mathrm{C}$ was downregulated. Furthermore, CNN1 and TAGLN were down-regulated in the intestinal proteome in Lean fish. Collagen, the main component of connective tissue, helps to maintain the structural integrity of tissues [75], while osteonectin is an extracellular matrix glycoprotein with high affinity towards collagen and whose expression has been associated with remodelling processes in tissues, including human intestine during development/ morphogenesis and in diseased mucosa [76]. Troponin, TAGLN and CNN1 are all involved in actin binding, actin-myosin interaction and muscle contraction. The inverse regulation of troponins is not conflicting as they have different roles in actomyosin cross-bridge formation and contraction; binding of troponin $\mathrm{C}$ to $\mathrm{Ca}^{2+}$ induces conformational changes that counteract the inhibitory action of troponin I [77]. Expression of TAGLN transcript and protein showed opposite effects but a lack of correlation between transcriptomic and proteomic data is not unprecedented [78]. As discussed above, this result might also be explained by the presence of similar duplicated genes in Atlantic salmon that are regulated differently. Transcriptomic results were validated by RTqPCR for COL1A2, although only significantly when fish were fed the VO diet, for which fold changes were higher. In addition, in the microarray results differences in expression of structural proteins between family groups were consistently more accentuated in fish fed VO which could suggest a cumulative effect of diet. Furthermore, MYO was up-regulated in fish fed VO compared to FO but only in Lean fish (RT-qPCR), and significant diet $\times$ genotype interactions were found for alpha-actinin 1, tubulin beta-2 chain and procollagenlysine 2-oxoglutarate 5-dioxygenase 2 (Additional file 1), which were up-regulated in Lean salmon, compared to Fat, but only when fed VO. In cod, replacement of FO by $\mathrm{VO}$ resulted in changes in intestinal expression of structural genes with the potential to alter the structural and mechanical properties of the intestinal muscle layer, including a range of actin-binding transcripts [21].

The present study is the first investigation of the influence of genetic background of families with different flesh adiposity phenotypes on intestinal gene expression of a fish species. Effects were subtle and consequently their potential impacts difficult to fully assess. However, if genetic selection for families better adapted to alternative formulations is an approach taken in the future, the potential for genotype-specific differences being exacerbated when VO replaces dietary FO should be further examined to assess the consequences of these changes in intestinal gene expression.

\section{Conclusions}

Metabolic activity, particularly lipid and energy, of intestinal tissue responded to dietary lipid composition but was also affected by genotype. The LC-PUFA biosynthesis pathway, typically up-regulated when salmon are fed VO, was especially influenced by genetic background. The Lean fish showed an enhanced response to low dietary n-3 LC-PUFA and the expression of $\Delta 5 \mathrm{fad}$, $\Delta 6 \mathrm{fad}$, elovl5b and elovl 2 in the intestine showed high plasticity and was reflected in tissue biochemical composition indicating that their transcriptional regulation might be under feedback control by n-3 LC-PUFA, mainly DHA. Lower n-3 LC-PUFA in VO increased lipogenesis in Lean salmon, assessed by expression of FAS, while $\beta$-oxidation appeared unaffected, although transcripts involved in mitochondrial respiratory or electron transport chains were down-regulated, suggesting reduced activity in fish fed VO. Higher expression of genes and proteins involved in xenobiotic metabolism (CYP1A and EPHX2), antioxidant defence (CAT, HPX and PRDX1), and apoptosis (Casp3B) were observed in $\mathrm{VO}$-fed fish, suggesting they might be responding to higher levels of contaminants, particularly PAH, in the diet. However, the intestine appeared able to metabolize 
and detoxify xenobiotic substances potentially present in the diet without major deleterious effects. Nonetheless, the data suggest that further attention should be given to contaminants in VO in the future. On the other hand, the data indicate potential genotype-specific differences in the response of the intestinal transcriptome and proteome to dietary VO. These include potential changes in structural properties of the intestinal layer and defence against cellular stress suggesting the Lean group was more susceptible to diet-induced oxidative stress. Considering the possibility of selecting families better adapted to alternative diet formulations, and the central role of intestine as a major barrier to nutrients, contaminants and pathogens, greater attention should be given to this organ when evaluating the effects of diet and genotype.

\section{Methods}

\section{Feeding trial and sampling}

A dietary trial was conducted using two genetically characterized groups of Atlantic salmon (Salmo salar) postsmolts comprising full-sib families selected from a breeding program (Landcatch Natural Selection Ltd., Argyll, Scotland). The choice of the family groups was based on estimated breeding values (EBVs) of the parents for high or low flesh adiposity, assessed by Torry Fatmeter (Distell Industries, West Lothian, UK), a trait that was found to have a heritability ranging from 0.17 to 0.39 in this dataset. The two groups were created from four unrelated full-sib families; two families from the extreme lower end of the EBV distribution for flesh lipid content (Lean) and two families from the extreme upper end of the distribution (Fat). The average EBV for the lipid content of the Fat families was 2.00 percentage units higher than that of the Lean families, representing a standardised selection differential of 2.33 standard deviations. Assessment of the flesh and visceral lipid contents at the end of the trial confirmed differences in adiposity between the groups [5].

Two thousand fish of each group were stocked into eight $12 \times 5 \mathrm{~m}^{3}$ net pens at the Ardnish Fish Trials Unit (Marine Harvest Scotland, Lochailort, Scotland; 500 fish pen $\left.^{-1}\right)$. Duplicate pens of each group were fed one of two experimental diets (Skretting ARC, Stavanger, Norway) containing $25-32 \%$ fish meal, $40-45 \%$ plant meals and $27.5-30 \%$ oil (percentages varying according to pellet size) supplied either as standard northern FO or as a VO blend comprising rapeseed, palm and Camelina oils in a ratio of 5:3:2. Diets were formulated to fully satisfy the nutritional requirements of salmonid fish [79] and contained similar levels of PUFA but different n-3 and n-6 PUFA contents, $25.3 \%$ and $4.6 \%$ in the FO diet and $13.4 \%$ and $17.1 \%$ in the VO diet, respectively [5]. After 55 weeks, 25 fish per pen were sampled $24 \mathrm{~h}$ after the last meal. Fish were killed by a blow to the head following anaesthesia, and intestinal tissue (pyloric caeca) collected, immediately frozen in liquid nitrogen and stored at $-70^{\circ} \mathrm{C}$ prior to analyses. Further details can be found in Bell et al. [5].

\section{Lipid extraction and fatty acid analyses}

Total lipid from $1 \mathrm{~g}$ of intestine of four fish per treatment was extracted and determined gravimetrically [80], and fatty acid methyl esters (FAME) prepared by acidcatalysed transesterification of total lipid [81]. FAME were separated and quantified by gas chromatography as described in detail previously [5]. Significant differences in intestinal fatty acid composition were determined by two-way ANOVA $(\mathrm{p}<0.05)$ using the SPSS 16.0 statistical package (SPSS Inc., Chicago IL, USA).

\section{RNA extraction and purification}

Intestinal tissue $(0.2 \mathrm{~g})$ from six individuals per experimental group was homogenised in $2 \mathrm{~mL}$ TRI Reagent and total RNA isolated following manufacturer's instructions (Ambion, Applied Biosystems, Warrington, U.K.). RNA quantity and quality (integrity and purity) were assessed by gel electrophoresis and spectrophotometry (NanoDrop ND-1000, Thermo Scientific, Wilmington, U.S.A.), and $100 \mu \mathrm{g}$ of total RNA from each sample further cleaned by mini spin-column purification (RNeasy Mini Kit, Qiagen, Crawley, UK).

\section{Microarray hybridizations, image processing and statistical analysis}

The TRAITS/SGP (v.2.1) salmon 17k cDNA microarray described by Taggart et al. [33] was used (ArrayExpress accession: A-MEXP-1930). A dual-labelled experimental design was employed, with each sample being competitively hybridised against a common pooled-reference. The experiment comprised 2 genotypes (Lean/Fat) $\times 2$ diets $(\mathrm{VO} / \mathrm{FO}) \times 6$ biological replicates. Indirect labelling was employed for preparing the microarray targets. Antisense amplified RNA (aRNA) was produced from $500 \mathrm{ng}$ of purified total RNA per sample using the Amino Allyl MessageAmpTM II aRNA Amplification Kit as per manufacturer's instructions (Ambion, Applied Biosystems), followed by $\mathrm{Cy} 3$ (for samples) or Cy5 (for pooled reference) fluor (GE HealthCare, Buckinghamshire, U.K.) incorporation through dye-coupling reaction [10]. Microarray hybridizations were performed in a Lucidea semi-automated system (GE Healthcare) without pre-hybridization. For each array, every labelled biological replicate and corresponding pooled reference (40 pmol each dye, c. 150 ng aRNA) were combined and added to the hybridization solution. Two post-hybridization automatic washes followed by six manual washes to a final stringency of $0.1 \times$ SSC (EasyDipTM Slide staining system; 
Canemco Inc., Quebec, Canada) were performed before scanning.

Scanning was performed at $10 \mu \mathrm{m}$ resolution using an Axon GenePix 4200AL Scanner (MDS Analytical Technologies, Wokingham, Berkshire, U.K.). Laser power was constant (80\%) and "auto PMT" was enabled to adjust each channel at less than $0.1 \%$ feature saturation and Cy3/Cy5 mean intensity close to one. BlueFuse software (BlueGnome, Cambridge, U.K.) was used to identify features and extract fluorescence intensity values from TIF images. The resulting fluorescence intensity data (BlueFuse proprietary algorithm) and quality annotations for the 17,102 gene features were exported into the GeneSpring GX version 10.0.2 analysis platform (Agilent Technologies, Wokingham, Berkshire, U.K.) after undergoing block Lowess normalization. All control features were excluded from subsequent analyses. Data transformation and quality filtering were as in Morais et al. $[9,10]$. This gave a final list of 15,498 genes that were eligible for statistical analysis. Experimental annotations complied fully with minimum information about a microarray experiment (MIAME) guidelines [82] and experimental hybridisations are archived on the EBI ArrayExpress database (http://www.ebi.ac.uk/arrayexpress/) under accession number E-TABM-1173. Hybridization data were analysed in GeneSpring by two-way ANOVA, which examined the explanatory power of the variable diet and genotype and the interaction between the two, followed by Gene Ontology (GO) enrichment analysis of the significant lists of features, at a significance level of 0.05 . No multiple test correction was employed, as previous analyses, confirmed by RT-qPCR, indicated that such corrections are over-conservative for this type of data $[9,32]$.

\section{RT-qPCR gene expression analysis}

Expression of selected genes, for microarray validation and to further examine biological processes of interest, was studied by reverse transcription quantitative real time PCR (RT-qPCR), with target qPCR primer sequences given in Additional file 2. In addition, amplification of two reference genes, cofilin-2 and elongation factor- $1 \alpha(e l f-1 \alpha)$, was performed. One $\mu \mathrm{g}$ of columnpurified total RNA per sample was reverse transcribed into cDNA using the VersoTM cDNA kit (ABgene, Surrey, U.K.) using a mixture of random hexamers (400ng/ $\mu \mathrm{L})$ and anchored oligo-dT $(500 \mathrm{ng} / \mu \mathrm{L})$ at $3: 1(\mathrm{v} / \mathrm{v})$. Negative controls (no enzyme) were performed to check for genomic DNA contamination. A similar amount of cDNA was pooled from all samples and the remaining cDNA diluted 20-fold with water. RT-qPCR analysis used relative quantification with the amplification efficiency of each primer pair assessed by serial dilutions of the cDNA pool. Amplifications were carried out in duplicate using a Quantica machine (Techne, Cambridge, U.K.) in a final volume of $20 \mu \mathrm{l}$ containing 2-8 $\mu$ l diluted cDNA, $0.5 \mu \mathrm{M}$ of each primer and $10 \mu \mathrm{l}$ AbsoluteTM QPCR SYBR ${ }^{\circledR}$ Green mix (ABgene), with a systematic negative control (NTC-non template control). The qPCR profiles contained an initial activation step at $95^{\circ} \mathrm{C}$ for $15 \mathrm{~min}$, followed by $30-40$ cycles: $15 \mathrm{~s}$ at $95^{\circ} \mathrm{C}, 15 \mathrm{~s}$ at the specific primer pair annealing temperature (Ta; Additional file 2) and $15 \mathrm{~s}$ at $72^{\circ} \mathrm{C}$. After amplification, a melt curve was performed confirming a single product in each reaction, RT-qPCR product sizes checked by agarose gel electrophoresis, and identity of amplicons confirmed by sequencing. Gene expression was analysed using the relative expression software tool (REST 2008, http://www.genequantification.info/), employing a pair wise fixed reallocation randomisation test (10,000 randomisations) with efficiency correction [83].

\section{Protein extraction and labelling}

Six intestine samples (100 mg) per treatment were rapidly disrupted by homogenization and sonication on ice in $1 \mathrm{ml}$ of DIGE lysis/labeling buffer (7M Urea, 2M Thiourea, 4\% CHAPS and 30mM Tris, $\mathrm{pH} 8.5$ ) in the presence of $10 \mu \mathrm{l}$ of a protease inhibitor cocktail (ref. P8340, Sigma-Aldrich) and $4 \mu \mathrm{l}$ of $250 \mathrm{mM}$ EDTA. After centrifugation at $12,000 \times \mathrm{g}$ for $20 \mathrm{~min}$ at $4^{\circ} \mathrm{C}$, the supernatant was recovered and protein concentration determined (Quick Start Bradford Protein Assay Kit, ref. \# 500-0202, Bio-Rad). Protein $(500 \mu \mathrm{g})$ was purified by precipitation (ReadyPrepTM 2-D Cleanup kit, Bio-Rad) and the pellet re-suspended in DIGE lysis/labeling buffer at $\sim 5 \mu \mathrm{g} / \mu \mathrm{l}$.

Samples were labelled using CyDye DIGE fluors (5nmol labelling kit; GE Healthcare), following manufacturer's instructions. Three of the experimental replicates of each treatment $(50 \mu \mathrm{g}$ protein with $\mathrm{pH}$ corrected to 8.0-8.5) were labelled individually with 400 pmol Cy3 and the remaining three with 400 pmol Cy5. In addition, equal amounts of all experimental samples were pooled and $600 \mu \mathrm{g}$ of protein $(50 \mu \mathrm{g}$ per 2-D gel) were batchlabelled with Cy2. The three labelled samples, corresponding to two experimental samples and one internal reference pool, were then combined to have in each 2-D gel samples corresponding to fish fed either $\mathrm{FO}$ or $\mathrm{VO}$ within the same family group.

Two-dimensional (2-D) polyacrylamide gel electrophoresis Rehydration buffer (ReadyPrep 2-D starter kit, Bio-Rad) containing $0.2 \%$ DTT was added to the pooled protein samples to a final volume of $450 \mu \mathrm{l}$, which were loaded onto Immobiline DryStrip pH 3-11 NL, 24 cm IPG strips (GE Healthcare) by passive rehydration at room temperature overnight in the dark. Proteins were separated in the first dimension by isoelectric focusing at $20^{\circ} \mathrm{C}$ (Ettan IPGphor, GE Healthcare), applying increasing 
voltage until $200 \mathrm{~V}$ for $4 \mathrm{~h}$, increasing to $500 \mathrm{~V}$ over a period of $3 \mathrm{~h}$, then keeping the applied tension at a constant $1000 \mathrm{~V}$ for $1 \mathrm{~h}$, followed by a further increase to $8000 \mathrm{~V}$ over $90 \mathrm{~min}$, maintaining this voltage for almost $9 \mathrm{~h}$ (total of 79,200 Vh). After isoelectric focusing the strips were equilibrated in two $40 \mathrm{~min}$ steps using $50 \mathrm{mM}$ Tris- $\mathrm{HCl} \mathrm{pH} 8.8,6 \mathrm{M}$ urea, 30\% glycerol, $2 \%$ SDS buffer, to which $2 \%$ DTT (w/v) and $2.8 \%$ iodoacetamide (GE Healthcare) were added to produce reducing and alkylating buffers, respectively. The strips were loaded onto a $12.5 \%$ acrylamide gel cast between low fluorescence glass cassettes (EttanDALTsix gel caster system, GE Healthcare). The strips were overlaid with ReadyPrep Overlay Agarose (Bio-Rad) and the six gel cassettes run in the EttanDALT system in two steps: at $60 \mathrm{~mA}, 80 \mathrm{~V}$, $6 \mathrm{~W}$ (upper limits) for $1 \mathrm{~h}$, and then $240 \mathrm{~mA}, 500 \mathrm{~V}$, $78 \mathrm{~W}$ until the bromophenol blue dye front had run to $\sim 1 \mathrm{~cm}$ above the bottom of the gels. Laemmli buffers (250mM Tris, $1.92 \mathrm{M}$ glycine, 1\% SDS) were used in the lower (1X) and upper (2X) chambers, respectively.

\section{Gel imaging and analysis}

Labelled gels were scanned using a Typhoon TRIO (GE Healthcare) and Cy2, Cy3 and Cy5 images acquired using 520BP40, 580BP30 and 670BP30 laser emission filters, respectively, at 500 PMT and $100 \mu \mathrm{m}$ resolution. Images were cropped to remove extraneous areas prior to analysis (ImageQuantTL, GE Healthcare), and image analysis performed using DeCyder V7.0 (GE Healthcare). The estimated number of spots for each co-detection procedure was set at 10,000 and an exclusion filter was applied to remove spots with a volume lower than 30,000. Differential expression of protein spots was examined by two-way ANOVA at a significance level of 0.05. After verifying that significant spots were well matched across the gels, two pick lists were generated with a total of 22 and 45 spots for the diet and genotype factors, respectively (Figure 1; Additional files 3 and 4).

\section{Spot picking and protein identification by peptide fragment fingerprinting}

Four preparative gels were run under the conditions described above but with higher amounts of protein $(600$ and $1000 \mu \mathrm{g})$. They were stained with colloidal Coomassie and, whenever possible, spots were excised and sequenced in the Mass Spectrometry Laboratory ITQBUNL (Oeiras, Portugal), where in-gel digestion and extraction of the proteins from the gel was performed, followed by micropurification, and peptides identified by mass spectrometry (using an Applied Biosystems (ABI) 4800 MALDI TOF/TOF Analyzer). The search engine MASCOT was then used to identify and confirm protein ID's from the peptide mass fingerprinting (PMF; MS) and peptide fragment fingerprinting (PFF; MS/MS) data.

\section{Additional files}

Additional file 1: Intestine transcripts corresponding to the top 100 most significant features exhibiting a significant diet $\times$ family interaction.

Additional file 2: Primers used for RT-qPCR analyses [84-89].

Additional file 3: 2D-gels pick list for the factor diet.

Additional file 4: 2D-gels pick list for the factor genotype.

Competing interests

The authors declare that they have no competing interests.

\section{Authors' contributions}

SM performed laboratory work and data analysis, with assistance from TS and OC in proteomics; DRG was responsible for family selection; JBT and JEB supported the microarray analysis; PR supported the proteomic analysis; SM wrote the first draft of the manuscript, followed by contributions from remaining authors; SM, JGB and DRT planned and coordinated the research; JGB and DRT were project leaders. All authors read and approved the final manuscript.

\section{Acknowledgements}

This study was funded by the EU FP6 IP "AQUAMAX" (Sustainable Aquafeeds to Maximise the Health Benefits of Farmed Fish for Consumers; 016249-2) SM was supported by a Marie Curie Intra European Fellowship (FP7-PEOPLE2007-2-1-IEF, Proposal N219667) and by AQUAGENOME Mobility and Resource Exchange Grants in 2008. The authors acknowledge Landcatch Ltd for provision of the Lean and Fat smolts and thank staff of Marine Harvest Ltd, Ardnish FTU, for assistance with fish husbandry and sample collection. Technical assistance from Jacquie Ireland in microarray hybridizations is deeply appreciated. We also acknowledge Mahaut de Vareilles for performing some of the protein identifications by mass spectrometry, and discussions on the use of DeCyder V7.0.

\section{Author details}

${ }^{1}$ Institute of Aquaculture, University of Stirling, Stirling FK9 4LA, Scotland, UK. ${ }^{2}$ Aquaculture Research Group, Centre of Marine Sciences (CCMAR), University of Algarve, 8005-139 Faro, Portugal. ${ }^{3}$ Landcatch Natural Selection Ltd.,

Cooperage Way Business Centre, Alloa FK10 3LP, Scotland, UK.

Received: 14 December 2011 Accepted: 24 August 2012

Published: 4 September 2012

\section{References}

1. Calder PC, Yaqoob P: Omega-3 polyunsaturated fatty acids and human health outcomes. Biofactors 2009, 35:266-272.

2. FAO: The State of World Fisheries and Aquaculture (SOFIA) 2010. Rome: Food and Agriculture Organization of the United Nations; 2010.

3. Tacon AGJ, Metian M: Global overview on the use of fish meal and fish oil in industrially compounded aquafeeds: Trends and future prospects. Aquaculture 2008, 285:146-158.

4. Torstensen BE, Espe M, Sanden M, Stubhaug I, Waagbø R, Hemre G-I, Fontanillas R, Nordgarden U, Hevrøy EM, Olsvik P, Berntssen MHG: Novel production of Atlantic salmon (Salmo salar) protein based on combined replacement of fish meal and fish oil with plant meal and vegetable oil blends. Aquaculture 2008, 285:193-200.

5. Bell JG, Pratoomyot J, Strachan F, Henderson RJ, Fontanillas R, Hebard A, Guy DR, Hunter D, Tocher DR: Growth, flesh adiposity and fatty acid composition of Atlantic salmon (Salmo salar) families with contrasting flesh adiposity: Effects of replacement of dietary fish oil with vegetable oils. Aquaculture 2010, 306:225-232.

6. Jordal AE, Torstensen BE, Tsoi S, Tocher DR, Lall SP, Douglas SE: Dietary rapeseed oil affects the expression of genes involved in hepatic lipid metabolism in Atlantic salmon (Salmo salar L.). J Nutr 2005, 135:2355-2361.

7. Panserat S, Kolditz C, Richard N, Plagnes-Juan E, Piumi F, Esquerré D, Médale F, Corraze G, Kaushik S: Hepatic gene expression profiles in juvenile rainbow trout (Oncorhynchus mykiss) fed fishmeal or fish oil-free diets. Br J Nutr 2008, 100:953-967. 
8. Panserat S, Hortopan GA, Plagnes-Juan E, Kolditz C, Lansard M, Skiba-Cassy S, Esquerre D, Geurden I, Médale F, Kaushik S, Corraze G: Differential gene expression after total replacement of dietary fish meal and fish oil by plant products in rainbow trout (Oncorhynchus mykiss) liver. Aquaculture 2009, 294:123-131.

9. Morais S, Pratoomyot J, Taggart JB, Bron JE, Guy DR, Bell JG, Tocher DR: Genotype-specific responses in Atlantic salmon (Salmo salar) subject to dietary fish oil replacement by vegetable oil: a liver transcriptomic analysis. BMC Genomics 2011, 12:255.

10. Morais S, Pratoomyot J, Torstensen BE, Taggart JB, Guy DR, Bell JG, Tocher DR: Diet $x$ genotype interactions in hepatic cholesterol and lipoprotein metabolism in Atlantic salmon (Salmo salar) in response to replacement of dietary fish oil with vegetable oil. Br J Nutr 2011, 106:1457-1469.

11. Geay F, Ferraresso S, Zambonino-Infante JL, Bargelloni L, Quentel C, Vandeputte M, Kaushik S, Cahu CL, Mazurais D: Effects of the total replacement of fish-based diet with plant-based diet on the hepatic transcriptome of two European sea bass (Dicentrarchus labrax) half-sibfamilies showing different growth rates with the plant-based diet. BMC Genomics 2011, 12:522.

12. Murray HM, Lall SP, Rajaselvam R, Boutilier LA, Blanchard B, Flight RM, Colombo S, Mohindra V, Douglas SE: A nutrigenomic analysis of intestinal response to partial soybean meal replacement in diets for juvenile Atlantic halibut, Hippoglossus hipploglossus, L. Aquaculture 2010, 298:282-293.

13. Skugor S, Grisdale-Helland B, Refstie S, Afanasyev S, Vielma J, Krasnov A: Gene expression responses to restricted feeding and extracted soybean meal in Atlantic salmon (Salmo salar L.). Aquacult Nutr 2011 doi:10.1111/j.1365-2095.2010.00832.x

14. Bell MV, Dick JR, Porter AEA: Pyloric ceca are a major site of 22:6n-3 synthesis in rainbow trout (Oncorhynchus mykiss). Lipids 2003, 39:39-44.

15. Fonseca-Madrigal J, Bell JG, Tocher DR: Nutritional and environmental regulation of the synthesis of highly unsaturated fatty acids and of fatty-acid oxidation in Atlantic salmon (Salmo salar L.) enterocytes and hepatocytes. Fish Physiol Biochem 2006, 32:317-328.

16. Caballero MJ, Obach A, Rosenlund G, Montero D, Gisvold M, Izquierdo MS: Impact of different dietary lipid sources on growth, lipid digestibility, tissue fatty acid composition and histology of rainbow trout, Oncorhynchus mykiss. Aquaculture 2002, 214:253-271.

17. Caballero MJ, Izquierdo MS, Kjorsvik E, Montero D, Socorro J, Fernandez AJ, Rosenlund G: Morphological aspects of intestinal cells from gilthead seabream (Sparus aurata) fed diets containing different lipid sources. Aquaculture 2003, 225:325-340.

18. Olsen RE, Dragsnes BT, Myklebust R, Ringø R: Effect of soybean oil and soybean lecithin on intestinal lipid composition and lipid droplet accumulation of rainbow trout, Oncorhynchus mykiss Walbaum. Fish Physiol Biochem 2003, 29:181-192.

19. Olsen RE, Myklebust R, Kaino T, Ringø E: Lipid digestibility and ultrastructural changes in the enterocytes of Arctic char (Salvelinus alpinus L.) fed linseed oil and soybean lecithin. Fish Physiol Biochem 1999, 21:35-44.

20. Olsen RE, Myklebust R, Ringø E, Mayhew TM: The influences of dietary linseed oil and saturated fatty acids on caecal enterocytes in Arctic char (Salvelinus alpinus L.): a quantitative ultrastructural study. Fish Physiol Biochem 2000, 22:207-216.

21. Morais S, Edvardsen RB, Tocher DR, Bell JG: Transcriptomic analyses of intestinal gene expression of juvenile Atlantic cod (Gadus morhua) fed diets with Camelina oil as replacement for fish oil. Comp Biochem Physiol B, doi:10.1016/j.cbpb.2011.12.004.

22. Olsvik PA, Torstensen BE, Berntssen MHG: Effects of complete replacement of fish oil with plant oil on gastrointestinal cell death, proliferation and transcription of eight genes' encoding proteins responding to cellular stress in Atlantic salmon Salmo salar L. J Fish Biol 2007, 71:550-568.

23. Teitelbaum JE, Allan Walker W: Review: the role of omega 3 fatty acids in intestinal inflammation. J Nutr Biochem 2001, 12:21-32.

24. Leaver MJ, Taggart JB, Villeneuve L, Bron JE, Guy DR, Bishop SC, Houston RD, Matika O, Tocher DR: Heritability and mechanisms of $n-3$ long chain polyunsaturated fatty acid deposition in the flesh of Atlantic salmon. Comp Biochem Physiol Part D Genomics Proteomics 2011, 6:62-69.
25. Dale OB, Tørud B, Kvellestad A, Koppang HS, Koppang EO: From chronic feed-induced intestinal inflammation to adenocarcinoma with metastases in salmonid fish. Cancer Res 2009, 69:4355-4362

26. Burrells C, Williams PD, Southgate PJ, Crampton VO: Immunological, physiological and pathological responses of rainbow trout (Oncorhynchus mykiss) to increasing dietary concentrations of soybean proteins. Vet Immunol Immunopathol 1999, 72:277-288.

27. Kolditz $\mathrm{Cl}$, Paboeuf $\mathrm{G}$, Borthaire $\mathrm{M}$, Esquerré $\mathrm{D}$, SanCristobal $\mathrm{M}$, Lefèvre $\mathrm{F}$, Médale F: Changes induced by dietary energy intake and divergent selection for muscle fat content in rainbow trout (Oncorhynchus mykiss), assessed by transcriptome and proteome analysis of the liver. BMC Genomics 2008, 9:506.

28. Allendorf FW, Thorgaard GH: Tetraploidy and the evolution of salmonid fishes. In Evolutionary Genetics of Fishes. Edited by Turner BJ. New York: Plenum Press; 1984:55-93.

29. Jump DB, Clarke SD, Thelen A, Liimatta M, Ren B, Badin M: Dietary polyunsaturated fatty acid regulation of gene transcription. Prog Lipid Res 1996, 35:227-241.

30. Nakamura MT, Nara TY: Gene regulation of mammalian desaturases. Biochem Soc Trans 2002, 30:1076-1079.

31. Wang Y, Botolin D, Christian B, Busik J, Xu J, Jump DB: Tissue-specific, nutritional, and developmental regulation of rat fatty acid elongases. J Lipid Res 2005, 46:706-715.

32. Leaver MJ, Villeneuve LA, Obach A, Jensen L, Bron JE, Tocher DR, Taggart JB: Functional genomics reveals increases in cholesterol biosynthetic genes and highly unsaturated fatty acid biosynthesis after dietary substitution of fish oil with vegetable oils in Atlantic salmon (Salmo salar). BMC Genomics 2008, 9:299.

33. Taggart JB, Bron JE, Martin SAM, Seear PJ, Høyheim B, Talbot R, Carmichael SN, Villeneuve LAN, Sweeney GE, Houlihan DF, Secombes CJ, Tocher DR, Teale AJ: A description of the origins, designs and performance of the TRAITS-SGP Atlantic salmon Salmo salar L. CDNA microarray. J Fish Biol 2008, 72:2071-2094.

34. Morais S, Monroig O, Zheng X, Leaver MJ, Tocher DR: Highly unsaturated fatty acid synthesis in Atlantic salmon: characterization of ELOVL5- and ELOVL2-like elongases. Mar Biotechnol 2009, 1:627-639.

35. van Schothorst EM, Flachs P, Franssen-van Hal NL, Kuda O, Bunschoten A, Molthoff J, Vink C, Hooiveld GJ, Kopecky J, Keijer J: Induction of lipid oxidation by polyunsaturated fatty acids of marine origin in small intestine of mice fed a high-fat diet. BMC Genomics 2009, 10:110.

36. Leaver MJ, Boukouvala E, Antonopoulou E, Diez A, Favre-Krey L, Ezaz MT, Bautista JM, Tocher DR, Krey G: Three peroxisome proliferator-activated receptor isotypes from each of two species of marine fish. Endocrinology 2005, 146:3150-3162.

37. Rosen ED, Walkey CJ, Puigserver P, Spiegelman BM: Transcriptional regulation of adipogenesis. Genes Dev 2000, 14:1293-1307.

38. Schmid B, Rippmann JF, Tadayyon M, Hamilton BS: Inhibition of fatty acid synthase prevents preadipocyte differentiation. Biochem Biophys Res Commun 2005, 328:1073-1082.

39. Davidson $\mathrm{MH}$ : Mechanisms for the hypotriglyceridemic effect of marine omega-3 fatty acids. Am J Cardiol 2006, 98:27i-33i.

40. Mori T, Kondo H, Hase T, Tokimitsu I, Murase T: Dietary fish oil upregulates intestinal lipid metabolism and reduces body weight gain in C57BL/6J mice. J Nutr 2007, 137:2629-2634

41. Madsen L, Frøyland L, Kryvi H, Auwerx J, Staels B, Berge RK: The mitochondrion is the principal target for nutritional and pharmacological control of plasma triglyceride. Lipids 1999, 34(Suppl):S167.

42. Kjær MA, Vegusdal A, Gjøen T, Rustan AC, Todorcević M, Ruyter B: Effect of rapeseed oil and dietary $n-3$ fatty acids on triacylglycerol synthesis and secretion in Atlantic salmon hepatocytes. Biochim Biophys Acta 2008, 178:112-122.

43. Jacobs MN, Covaci A, Schepens P: Investigation of selected persistent organic pollutants in farmed Atlantic salmon (Salmo salar), salmon aquaculture feed, and fish oil components of the feed. Environ Sci Technol 2002, 36:2797-2805.

44. Bell JG, McGhee F, Dick JR, Tocher DR: Dioxin and dioxin-like polychlorinated biphenyls (PCBs) in Scottish farmed salmon (Salmo salar): effects of replacement of dietary marine fish oil with vegetable oils. Aquaculture 2005, 243:305-314 
45. Takahashi M, Tsuboyama-Kasaoka N, Nakatani T, Ishii M, Tsutsumi S, Aburatani $\mathrm{H}$, Ezaki O: Fish oil feeding alters liver gene expressions to defend against PPARa activation and ROS production. Am J Physiol Gastrointest Liver Physiol 2002, 282:G338-G348.

46. Saera-Vila A, Benedito-Palos L, Sitjà-Bobadilla A, Nácher-Mestre J, Serrano R, Kaushik S, Pérez-Sánchez J: Assessment of the health and antioxidant trade-off in gilthead sea bream (Sparus aurata L.) fed alternative diets with low levels of contaminants. Aquaculture 2009, 296:87-95.

47. Moore MJ, Mitrofanov IV, Valentini SS, Volkov W, Kurbskiy AV, Zhimbey EN, Eglinton LB, Stegeman JJ: Cytochrome P4501A expression, chemical contaminants and histopathology in roach, goby and sturgeon and chemical contaminants in sediments from the Caspian Sea, Lake Balkhash and the lly River Delta, Kazakhstan. Mar Pollut Bull 2003, 46:107-119.

48. Lee RF, Anderson JW: Significance of cytochrome P450 system responses and levels of bile fluorescent aromatic compounds in marine wildlife following oil spills. Mar Pollut Bull 2005, 50:705-723.

49. Bacanskas LR, Whitaker J, Di Giulio RT: Oxidative stress in two populations of killifish (Fundulus heteroclitus) with differing contaminant exposure histories. Mar Environ Res 2004, 58:597-601.

50. Galar-Martínez M, Gomez-Olivan LM, Amaya-Chavez A, Razo-Estrada C, Garcia-Medina S: Oxidative stress induced on Cyprinus carpio by contaminants present in the water and sediment of Madín Reservoir. J Environ Sci Health, Part A: Tox Hazard Subst Environ Eng 2010, 45;155-160.

51. Wood ZA, Schröder E, Robin Harris J, Poole LB: Structure, mechanism and regulation of peroxiredoxins. Trends Biochem Sci 2003, 28:32-40.

52. Tolosano E, Altruda F: Hemopexin: structure, function, and regulation. DNA Cell Biol 2002, 21:297-306

53. Burk RF, Hill KE, Motley AK: Selenoprotein metabolism and function: evidence for more than one function for selenoprotein P. J Nutr 2003, 133(5 Suppl 1):1517S-1520S.

54. Kang YJ: Metallothionein redox cycle and function. Exp Biol Med 2006, 231:1459-1467.

55. Berntssen MH, Julshamn K, Lundebye AK: Chemical contaminants in aquafeeds and Atlantic salmon (Salmo salar) following the use of traditional- versus alternative feed ingredients. Chemosphere 2010 78:637-646

56. Moret $\mathrm{S}$, Conte LS: Polycyclic aromatic hydrocarbons in edible fats and oils: occurrence and analytical methods. J Chromatogr A 2000, 882:245-253.

57. Shimada T: Xenobiotic-metabolizing enzymes involved in activation and detoxification of carcinogenic polycyclic aromatic hydrocarbons. Drug Metab Pharmacokinet 2006, 21:257-276.

58. Hellou J, Leonard J, Anstey C: Dietary exposure of finfish to aromatic contaminants and tissue distribution. Arch Environ Contam Toxicol 2002, 42:470-476

59. Yuen BB, Wong CK, Woo NY, Au DW: Induction and recovery of morphofunctional changes in the intestine of juvenile carnivorous fish (Epinephelus coioides) upon exposure to foodborne benzo[a]pyrene. Aquat Toxicol 2007, 82:181-194.

60. Zhang Y, Lu Y, Zhou H, Lee M, Liu Z, Hassel BA, Hamburger AW: Alterations in cell growth and signaling in ErbB3 binding protein-1 (Ebp1) deficient mice. BMC Cell Biol 2008, 9:69.

61. Celis JE, Madsen P, Celis A, Nielsen HV, Gesser B: Cyclin (PCNA, auxiliary protein of DNA polymerase delta) is a central component of the pathway(s) leading to DNA replication and cell division. FEBS Lett 1987, 220:1-7

62. Liu Z, Ahn JY, Liu X, Ye K: Ebp1 isoforms distinctively regulate cell survival and differentiation. Proc Natl Acad Sci USA 2006, 103:10917-10922.

63. Sweet LI, Passino-Reader DR, Meier PG, Omann GM: Xenobiotic-induced apoptosis: significance and potential application as a general biomarker of response. Biomarkers 1999, 4:237-253.

64. Ramachandran A, Madesh M, Balasubramanian KA: Apoptosis in the intestinal epithelium: its relevance in normal and pathophysiological conditions. J Gastroenterol Hepatol 2000, 15:109-120.

65. Paclik D, Lohse K, Wiedenmann B, Dignass AU, Sturm A: Galectin-2 and -4, but not galectin-1, promote intestinal epithelial wound healing in vitro through a TGF-beta-independent mechanism. Inflamm Bowel Dis 2008, 14:1366-1372.

66. Loser K, Sturm A, Voskort M, Kupas V, Balkow S, Auriemma M, Sternemann C, Dignass AU, Luger TA, Beissert S: Galectin-2 suppresses contact allergy by inducing apoptosis in activated CD8+ T cells. $\mathrm{J}$ Immunol 2009, 182:5419-5429.

67. Tsukamoto K, Miura F, Fujito NT, Yoshizaki G, Nonaka M: Long-Lived Dichotomous Lineages of the Proteasome Subunit Beta Type 8 (PSMB8) Gene Surviving More than 500 Million Years as Alleles or Paralogs. Mol Biol Evol 2012, doi:10.1093/molbev/mss113. May 2. [Epub ahead of print].

68. Nandi D, Tahiliani P, Kumar A, Chandu D: The ubiquitin-proteasome system. J Biosci 2006, 31:137-155

69. Widmer CC, Pereira CP, Gehrig P, Vallelian F, Schoedon G, Buehler PW Schaer DJ: Hemoglobin can attenuate hydrogen peroxide-induced oxidative stress by acting as an antioxidative peroxidase. Antioxid Redox Signal 2010, 12:185-198.

70. Shimizu S, Matsuoka Y, Shinohara Y, Yoneda Y, Tsujimoto Y: Essential role of voltage-dependent anion channel in various forms of apoptosis in mammalian cells. J Cell Biol 2001, 152:237-250.

71. Jeon YJ, Kim DH, Jung H, Chung SJ, Chi SW, Cho S, Lee SC, Park BC, Park SG, Bae KH: Annexin A4 interacts with the NF-kappaB p50 subunit and modulates NF-kappaB transcriptional activity in a Ca2+-dependent manner. Cell Mol Life Sci 2010, 67:2271-2281.

72. Parag HA, Raboy B, Kulka RG: Effect of heat shock on protein degradation in mammalian cells: involvement of the ubiquitin system. EMBO J 1987, 6:55-61.

73. Raboy B, Sharon G, Parag HA, Shochat Y, Kulka RG: Effect of stress on protein degradation: role of the ubiquitin system. Acta Biol Hung 1991, 42:3-20.

74. Pirkkala L, Alastalo TP, Zuo X, Benjamin IJ, Sistonen L: Disruption of heat shock factor 1 reveals an essential role in the ubiquitin proteolytic pathway. Mol Cell Biol 2000, 20:2670-2675.

75. Di Lullo GA, Sweeney SM, Korkko J, Ala-Kokko L, San Antonio JD: Mapping the ligand-binding sites and disease-associated mutations on the most abundant protein in the human, type I collagen. J Biol Chem 2002, 277:4223-4231.

76. Lussier C, Sodek J, Beaulieu JF: Expression of SPARC/osteonectin/BM4O in the human gut: predominance in the stroma of the remodeling distal intestine. J Cell Biochem 2001, 81:463-476.

77. Layland J, Solaro RJ, Shah AM: Regulation of cardiac contractile function by troponin I phosphorylation. Cardiovasc Res 2005, 66:12-21.

78. Olivares-Hernández R, Usaite R, Nielsen J: Integrative analysis using proteome and transcriptome data from yeast to unravel regulatory patterns at post-transcriptional level. Biotechnol Bioeng 2010 107:865-875.

79. National Research Council (NRC): Nutrient requirements of fish and shrimp. Washington: National Academy Press; 2011.

80. Folch J, Lees M, Sloane-Stanley GH: A simple method for the isolation and purification of total lipides from animal tissues. J Biol Chem 1957, 226:497-509.

81. Christie WW: Lipid analysis. 3rd edition. Bridgewater, UK: The Oily Press: 2003.

82. Brazma A, Hingamp P, Quackenbush J, Sherlock G, Spellman P, Stoeckert C, Aach J, Ansorge W, Ball CA, Causton HC, Gaasterland T, Glenisson P, Holstege FC, Kim IF, Markowitz V, Matese JC, Parkinson H, Robinson A, Sarkans U, Schulze-Kremer S, Stewart J, Taylor R, Vilo J, Vingron M: Minimum information about a microarray experiment (MIAME)-toward standards for microarray data. Nat Genet 2001, 29:365-371.

83. Pfaffl MW, Horgan GW, Dempfle L: Relative expression software tool (REST) for group-wise comparison and statistical analysis of relative expression results in real-time PCR. Nucleic Acids Res 2002, 30:e36.

84. Zheng X, Tocher DR, Dickson CA, Bell JG, Teale AJ: Highly unsaturated fatty acid synthesis in vertebrates: new insights with the cloning and characterization of a $\Delta 6$ desaturase of Atlantic salmon. Lipids 2005, 40:13-24.

85. Torstensen BE, Nanton DA, Olsvik PA, Sundvold H, Stubhaug I: Gene expression of fatty acid-binding proteins, fatty acid transport proteins (cd36 and FATP) and $\beta$-oxidation-related genes in Atlantic salmon (Salmo salar L.) fed fish oil or vegetable oil. Aquacult Nutr 2009, 15:440-451.

86. Rees CB, Li W: Development and application of a real-time quantitative $P C R$ assay for determining CYP1A transcripts in three genera of salmonids. Aquat Toxicol 2004, 66:357-368.

87. Kleveland EJ, Ruyter B, Vegusdal A, Sundvold H, Berge RK, Gjøen T: Effects of 3-thia fatty acids on expression of some lipid related genes in Atlantic 
salmon (Salmo salar L.). Comp Biochem Physiol B Biochem Mol Biol 2006, 145:239-248.

88. Olsvik PA, Kristensen T, Waagbø R, Rosseland BO, Tollefsen KE, Baeverford G, Berntssen MHG: mRNA expression of antioxidant enzymes (SOD, CAT and GSH-Px) and lipid peroxidative stress in liver of Atlantic salmon (Salmo salar) exposed to hyperoxic water during smoltification. Comp Biochem Physiol C Toxicol Pharmacol 2005, 141:314-323.

89. Takle H, McLeod A, Andersen O: Cloning and characterization of the executioner caspases 3, 6, 7 and Hsp70 in hyperthermic Atlantic salmon (Salmo salar) embryos. Comp Biochem Physiol B Biochem Mol Biol 2006, 144:188-198.

doi:10.1186/1471-2164-13-448

Cite this article as: Morais et al: Effects of genotype and dietary fish oil replacement with vegetable oil on the intestinal transcriptome and proteome of Atlantic salmon (Salmo salar). BMC Genomics 2012 13:448.

\section{Submit your next manuscript to BioMed Central and take full advantage of:}

- Convenient online submission

- Thorough peer review

- No space constraints or color figure charges

- Immediate publication on acceptance

- Inclusion in PubMed, CAS, Scopus and Google Scholar

- Research which is freely available for redistribution 